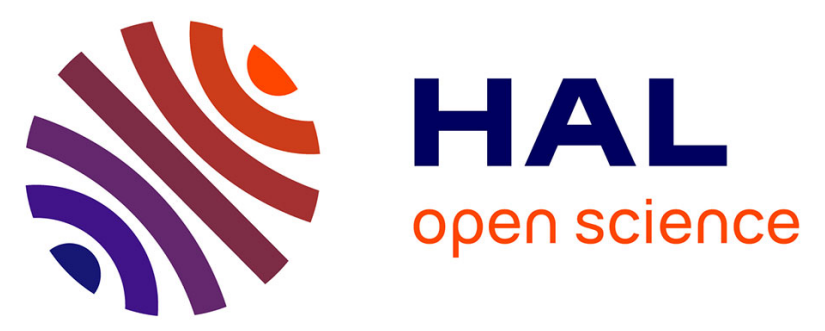

\title{
Insights into the new cadmium(II) metalloporphyrin Synthesis, X-ray crystal structure, Hirshfeld surface analysis, photophysical and cyclic voltammetry characterization of the (morpholine) (meso-tetra(para- chloro-phenyl)porphyrinatocadmium(II)
}

C. Mchiri, S. Dhifaoui, K. Ezzayani, M. Guergueb, Thierry Roisnel, F. Loiseau, H. Nasri

\section{- To cite this version:}

C. Mchiri, S. Dhifaoui, K. Ezzayani, M. Guergueb, Thierry Roisnel, et al.. Insights into the new cadmium(II) metalloporphyrin Synthesis, X-ray crystal structure, Hirshfeld surface analysis, photophysical and cyclic voltammetry characterization of the (morpholine)(meso-tetra(para-chlorophenyl)porphyrinatocadmium(II). Polyhedron, 2019, 171, pp.10-19. 10.1016/j.poly.2019.06.055 . hal02281772

\section{HAL Id: hal-02281772}

https://hal-univ-rennes1.archives-ouvertes.fr/hal-02281772

Submitted on 16 Dec 2019

HAL is a multi-disciplinary open access archive for the deposit and dissemination of scientific research documents, whether they are published or not. The documents may come from teaching and research institutions in France or abroad, or from public or private research centers.
L'archive ouverte pluridisciplinaire HAL, est destinée au dépôt et à la diffusion de documents scientifiques de niveau recherche, publiés ou non, émanant des établissements d'enseignement et de recherche français ou étrangers, des laboratoires publics ou privés. 


\title{
Insights into the New Cadmium(II) Metalloporphyrin: Synthesis, X-ray Crystal Structure, Hirshfeld surface analysis, Photophysical and Cyclic voltammetry Characterization of the (Morpholine)\{(meso-tetra(para- chloro-phenyl)porphyrinato\} cadmium(II)
}

\author{
Chadlia Mchiri a, Selma Dhifaoui a khaireddine Ezzayani a, Mouhieddinne Guergueb a, Thierry \\ Roisnel $^{b}$ Fredérique Loiseau ${ }^{c}$ and Habib Nasri a \\ a Laboratoire de Physico-chimie des Matériaux, Faculté des Sciences de Monastir, Avenue de l'environnement, 5019 \\ Monastir, University of Monastir, Tunisia. \\ ${ }^{b}$ Centre de Diffractométrie X, Institut des Sciences Chimiques de Rennes, UMR 6226, CNRS-Université de Rennes,1, \\ Campus de Beaulieu, 35042 Rennes Cedex, France. \\ 'Département de Chimie Moléculaire, Université Grenoble-Alpes, CNRS UMR 5250, BP53 38041 Grenoble, France.
}

\begin{abstract}
Absract
In this work we report the synthesis of the cadmium(II)-meso-tetra(para-chlorophenyl)porphyrin with the morpholine $O$-donor axial ligand with formula [Cd(TClPP)(morph)] (I). This coordination compound adopts a distorted five-coordinate square pyramidal geometry indicated by a major doming, a moderate ruffling and saddle distortions of the porphyrinato core. The supramolecular architecture is dominated by intermolecular $\mathrm{N}-\mathrm{H} \cdots \mathrm{Cl}$ and $\mathrm{C}-\mathrm{H} \cdots \mathrm{Cl}$ interactions formed between the morpholine and the chlorine atom of the adjacent meso-phenylporphyrin of complex (I). Hirshfeld surface analysis was carried out to understand the nature of intermolecular contacts, where the fingerprint plot provides the information about the percentage contribution. UV-visible spectroscopy study highlighted the red-shift of the absorption bands after the insertion of Cd(II) metal ion into TCIPP moiety and after coordination of the morpholine axial ligand. Fluorescence emission spectroscopy study showed a remarkable blue-shift effect of the Q bands followed by a dramatical diminution of the fluorescence intensity, quantum yield $\left(\varphi_{\mathrm{f}}\right)$ and lifetime $\left(\tau_{\mathrm{f}}\right)$ as consequence of the high quenching effect of the cadmium heavy metal and the distortion of the porphyrin core, which promotes the loss of the "motion energy" by other non-radiative energy dissipation processes than light emission. An increase of the singlet oxygen quantum yield $\left(\Phi_{\Delta}\right)$ is also observed due to the heavy atom effect of cadmium(II) cation. The cyclic voltammetry investigation of the free base $\mathrm{H}_{2} \mathrm{TClPP}$, the starting material $[\mathrm{Cd}(\mathrm{TClPP})]$ and the $\mathrm{Cd}(\mathrm{II})$-morpholine porphyrin species (I) is also reported.
\end{abstract}

Keywords: Cadmium(II) porphyrin coordination compound, X-ray crystal structure, Hirshfeld surfaces, Fluorescence, Singlet Oxygen, . 


\section{Introduction}

The chemistry of porphyrins and related compounds dates back to the late nineteen century. The porphyrin species and metalloporphyrins complexes are currently used in a variety of applications such as photodynamic therapy, [1-3] optoelectronics, [4-5] chemical sensors, [6] catalysis, [7] and photovoltaic systems [8]. Much of the excitement in porphyrin research lies in their modular and relatively facile synthesis, large size, ready dissolution in organic solvents, characteristic colors, rigidity, thermal stability, and affinity for metallation [9]. Since the middle of the last century, cadmium porphyrins have been studied and the physical and chemical properties of Cd-porphyrin derivatives have been of general interest. Cadmium(II) ion is too big to fit co-planarly into the cavity of porphyrin, it is located out of the ligand plane and distorts it. Therefore the structure deformation of cadmium(II) metalloporphyrins results in kinetic lability as well as peculiar photophysical and photochemical behavior [10-11]. By the other hand, both cadmium and porphyrin exhibit rich coordination chemistry. In fact, the $\mathrm{Cd}^{2+}$ site shows equally diverse coordination modes and exists in five different coordination environments [12]. However, it has been noticed that for porphyrins, cadmium(II) can coordinated only one axial ligand to form fivecoordinated complexes [13]. This makes cadmium metalloporphyrins simple systems to evaluate the effect of the type of the axial ligands on the electronic and structural properties of porphyrin coordination compounds.

It is noteworthy that cadmium porphyrin derivatives exhibit several biological applications. In this context, we can mention the investigations in 2001 of Nyarko et al., [14] which reported the interactions of cadmium(II), mercury(II), and lead(II) metalloporphyrins with DNA and their effects on this enzyme. Due to the fact that $\mathrm{Cd}(\mathrm{II}), \mathrm{Hg}(\mathrm{II})$ and $\mathrm{Pb}$ (II) are large divalent cations, which are known to dissociate from their metalloporphyrin complexes in the presence of DNA and ethylenediamine tetraacetic acid (EDTA). This is not the case of $\mathrm{d}$ transition center metals such as $\mathrm{Mn}^{3+}, \mathrm{Fe}^{3+}$ and $\mathrm{Co}^{3+}$, the characteristic effects of the already mentioned heavy divalent cations are expected to influence the DNA cleavage reaction. More recently, in 2012, Lee et al; [15] noticed that hydrolysis of carbon dioxide is an important reaction for $\mathrm{CO}_{2}$ collection by using accurate first-principles electronic structure calculations. These authors, predict how the catalytic hydrolysis reaction in carbonic anhydrase (CA) can be mimicked in a zinc(II) and cadmium(II) metalloporphyrins - carbon nanotube system. 
Notably, morpholine is widely used as a solvent and it possesses two sites for coordination to the metal ions. In the literature, are reported the spectroscopic properties of the morpholine with divalent metallo-tetraphenyl porphyrins type $[\mathrm{M}(\mathrm{TPP})](\mathrm{M}=\mathrm{Co}(\mathrm{II})$, $\mathrm{Cu}(\mathrm{II}), \mathrm{Ni}(\mathrm{II})$ and $\mathrm{Zn}(\mathrm{II})$ ), which elucidate the nature of ligation and the binding site of the morpholine [16].

Nevertheless, up to date no reported investigation on the effect of the coordination of morpholine axial ligand to the structural, spectroscopic, photophysical and electrochemical properties of metalloporphyrins. In this work, we report the first example of the reaction of a $\mathrm{Cd}(\mathrm{II})$-porphyrin complex with the morpholine leading to the (morpholine)[(meso-tetrakis(4chlorophenyl)porphyrinato]cadmium(II) complex with the formula [Cd(TClPP)(morph)] (I) (Scheme 1) where the morpholine axial ligand is bonded to the cadmium through the oxygen atom.

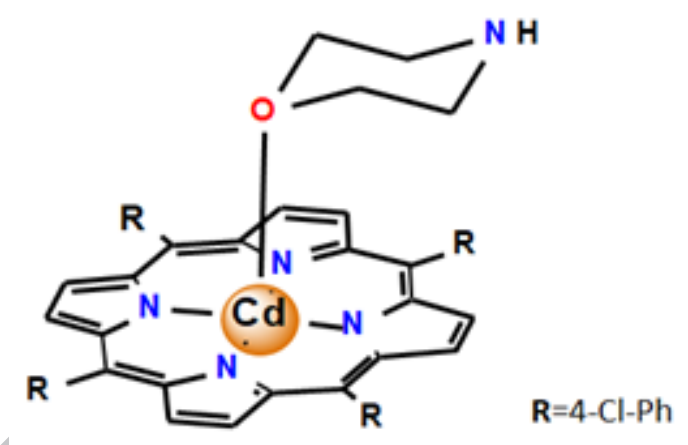

[CdCIPP(morph)]

Scheme 1. Structure of [Cd(TClPP)(morph)] (I).

\section{Experimental Section}

\subsection{Syntheses}

The synthesis of the meso-tetrakis(para-chlorophenyl)porphyrin $\left(\mathrm{H}_{2} \mathrm{TClPP}\right)$ and the [mesotetrakis(para-chlorophenyl)porphyrinato)]cadmium(II) starting material complex [Cd(TCIPP)] were performed according to the methods described in the literature [17-18]. Scheme $\mathrm{S} 1$ gives the main steps of the preparation method.

$\mathbf{H}_{2}$ TCIPP porphyrin was obtained as purple crystals with $21 \%$ yield. ${ }^{1} \mathrm{H}$ NMR $(300 \mathrm{MHz}$, DMSO-d6): $\delta$ (ppm.) -2.84 (s, 2H, N-H), 7.77 (d, 8H, Hm-Ph), 8.15 (d, 8H, Ho-Ph), 8.86 (s, $8 \mathrm{H}, \beta$-pyr). UV-vis $\left[\lambda_{\max }(\mathrm{nm})\right.$ in $\left.\mathrm{CH}_{2} \mathrm{Cl}_{2},\left(\varepsilon \times 10^{-3}, \mathrm{~mol}^{-1} \cdot \mathrm{L} \mathrm{cm}^{-1}\right)\right]$ 420(309), 517(15.8), 553(11), 589(5.6), 645(2). FTR-IR cm ${ }^{-1}: 3316 v$ [(NH) porphyrin], $2960 v[(\mathrm{CH})$ porphyrin], $967[(\delta \mathrm{CCH})$ porphyrin], $780 v(\mathrm{C}-\mathrm{Cl})$. 
[Cd(TCIPP)] was obtained as a dark green solid with $85 \%$ yield. ${ }^{1} \mathrm{H}$ NMR $(300 \mathrm{MHz}$, DMSO-d $\left._{6}\right) \delta(\mathrm{ppm}), 8.11\left(\mathrm{~d}, 8 \mathrm{H}, \mathrm{H}_{\mathrm{o}-\mathrm{Ph}}\right), 7.97$ (d, 8H, $\left.\mathrm{H}_{\mathrm{m}-\mathrm{Ph}}\right), 8.75$ (s, 8H, $\beta$-pyr). UV/vis $\left(\mathrm{CH}_{2} \mathrm{Cl}_{2}\right),\left[\lambda_{\max }(\mathrm{nm})\right.$ in $\left.\mathrm{CH}_{2} \mathrm{Cl}_{2},\left(\varepsilon \times 10^{-3}, \mathrm{~mol}^{-1} \mathrm{x} \mathrm{L} \mathrm{x} \mathrm{cm}{ }^{-1}\right)\right]: 433$ (117), 568(2.3), 609(2.6). FTR-IR cm ${ }^{-1}: 2926 v[(\mathrm{CH})$ porphyrin], 1086 [( $\delta \mathrm{CCH})$ porphyrin], $720 v(\mathrm{C}-\mathrm{Cl})$.

[Cd(TCIPP)(morph)] (I) [Cd(TClPP)] $(20 \mathrm{mg}, 0.020 \mathrm{mmol})$ and morpholine $(0.5 \mathrm{~mL}$, $0.125 \mathrm{mmol}$ ) were dissolved in $3 \mathrm{~mL}$ of chloroform. The solution was stirred overnight before to be filtrated. Crystals of complex (I) were obtained by slow diffusion of hexane into the chloroform solution with $80 \%$ yield (Scheme S1). Elemental analysis (\%) calcd for $\mathrm{C}_{48} \mathrm{H}_{33} \mathrm{Cl}_{4} \mathrm{CdN}_{5} \mathrm{O}$ (950.04). C, 60.68, H, 3.51, N, 7.37; found : C, 60.81, H, 3.59, N, 7.49. ${ }^{1} \mathrm{H}$ NMR (300 MHz, DMSO-d6) $\delta(\mathrm{ppm}), 2.64$ (t, 4Hb, morph), 3.47 (t, 4Ha, morph); 5.75 (s, Hc, NH morph), 7.97 (d , 8H, $\mathrm{H}_{\mathrm{m}-\mathrm{Ph}}$ ), 8.21 (d, 8H ,Ho-Ph), 8.74 (s, 8H, $\beta$-pyr). UV/vis $\left(\mathrm{CH}_{2} \mathrm{Cl}_{2}\right),\left[\lambda_{\max }(\mathrm{nm})\right.$ in $\left.\mathrm{CH}_{2} \mathrm{Cl}_{2},\left(\varepsilon \times 10^{-3}, \mathrm{~mol}^{-1} \mathrm{~L} \mathrm{~cm}^{-1}\right)\right]$ : 436 (126), 575(4.4), 620(2.6). FTR-IR $\left(\mathrm{cm}^{-1}\right): 2849 v[(\mathrm{CH})$ porphyrin], 1089 [( $8 \mathrm{CCH})$ porphyrin], $3293 v(\mathrm{~N}-\mathrm{H})_{\text {morph }}, 1387$ $v(\mathrm{C}-\mathrm{O})_{\text {morph }}, 719 v(\mathrm{C}-\mathrm{Cl})$.

\subsection{Spectroscopic and photophysical measurements:}

${ }^{1} \mathrm{H}$ spectra were recorded using Brucker Advance 300 spectrometer. The spectra were recorded in DMSO- $d_{6}$ solutions at room temperature $(\mathrm{T}=298 \mathrm{~K})$ using DMSO residual peaks $(\delta=2.50 \mathrm{ppm})$ as internal references. Chemical shifts $(\delta)$ and coupling constants $(J)$ are given in parts per million (ppm) and Hertz (Hz), respectively. Multiplicities are reported as follow: $\mathrm{s}=$ singlet, $\mathrm{d}=$ doublet, $\mathrm{t}=$ triplet, $m-\mathrm{Ph}$ and $o-\mathrm{Ph}=$ meta and ortho protons on the phenyl rings, and $\beta$-pyr $=\beta$-pyr protons on the pyrrole rings. Infrared spectra were recorded from 4000 to $400 \mathrm{~cm}^{-1}$ FT-IR Nexus (Nicolet) spectrometer. Absorbance spectra were recorded on a UV-3600 Shimadzu spectrophotometer and the concentrations of porphyrin derivatives were controlled to be $c a .10^{-5} \mathrm{M}$ in $\mathrm{CH}_{2} \mathrm{Cl}_{2}$. Fluorescence spectra were recorded on a Fluorolog-3 spectrofluorimeter FL3-222 with a thermostated cell compartment $\left(25{ }^{\circ} \mathrm{C}\right)$ using a $450 \mathrm{~W}$ Xenon lamp and the concentrations of porphyrin derivatives were controlled to be $c a \cdot 10^{-6} \mathrm{M}$ in $\mathrm{CH}_{2} \mathrm{Cl}_{2}$. The singlet oxygen production 30 was measured by the IR detector through a SPEX double grating monochromator (600 grooves $/ \mathrm{mm}$ blazed at $1 \mu \mathrm{m}$ ). All spectra were recorded using four optical faces quartz cells. Fluorescence quantum yield $\left(\varphi_{\mathrm{f}}\right)$ were determined using tetraphenyl porphyrin $\left(\mathrm{H}_{2} \mathrm{TPP}\right)$ solution in toluene as fluorescence standard $\left(\varphi_{\mathrm{f}}=0.11\right)$ [19]. $\mathrm{H}_{2}$ TPP in toluene was used as standard $\left(\Phi_{\Delta}=0.63\right)$ [20]. The absorbance value at the excitation wavelength of the reference and the sample 
solutions were set to around 0.2. The fluorescence decays were recorded using the single photon counting method. Data were collected up to 1000 counts accumulated in the maximum channel and analyzed using Time Correlated Single Photon Counting (TCSPC) software Fluofit (PicoQuant GmbH, BERLIN, Germany) based on iterative reconvolution using a Levensberg-Marquandt algoritm, enabling the obtention of multi-exponential profiles (mainly one or two exponentials in our cases).

\section{3 cyclic voltammetry}

Cyclic voltammetry $(\mathrm{CV})$ experiments were performed with a $\mathrm{CH}-660 \mathrm{~B}$ potentiostat $(\mathrm{CH}$ Instruments). The analytical experiment is conducted at room temperature under an argon atmosphere in a standard one-compartment, three-electrode electrochemical cell. Tetra-nbutylammonium perchlorate (TBAP) was used as the supporting electrolyte $(0.2 \mathrm{~m})$ in dichloromethane. An automatic Ohmic drop compensation procedure was systematically implemented before the $\mathrm{CV}$ data were recorded with electrolytic solutions containing the studied compounds at concentrations of ca. $10^{-3} \mathrm{M}$. CH Instruments vitreous carbon ( $\mathrm{f}=3$ $\mathrm{mm}$ ) working electrodes were polished with $1 \mu \mathrm{m}$ diamond paste before each recording. The $\mathrm{Ag} / \mathrm{AgNO} 3$ (TBAP $0.2 \mathrm{~m}$ in $\mathrm{CH}_{2} \mathrm{Cl}_{2}$ ) redox couple was used as the reference electrode and a platinum wire as an auxiliary electrode. For comparison with previously published data, all potentials given in the text have been converted to values relative to the saturated calomel electrode (SCE) by using the following relationship: $\mathrm{E}(\mathrm{SCE})=\mathrm{E}\left(\mathrm{Ag} / \mathrm{AgNO}_{3}\right)+298 \mathrm{mV}$.

\subsection{X-ray Crystallography}

Single crystals of $[\mathrm{Cd}(\mathrm{TClPP})(\mathrm{morph})]$ (I) were grown at room temperature from $\mathrm{CHCl}_{3^{-}}$ hexane mixture and carefully selected under a microscope and mounted on a Mitegen micromesh with the help of a trace of mineral oil. on a D8 VENTURE Bruker AXS diffractometer equipped with a graphite monochromatic Mo-K radiation source $(\lambda=0.71073$ $\AA)$. The unit-cell parameters were calculated and refined from the full data and the data collection was performed with a Bruker D8 VENTURE diffractometer at $150 \mathrm{~K}$. The reflections were scaled and corrected for absorption effects by using Multi-Scan method [21]. The structure was solved by direct method by using SIR-2004 program [22] and refined by full-matrix least-squares techniques on $\mathrm{F}^{2}$ by using the SHELXL-97 program 
[23]. The drawings were made with Mercury [24]. Crystal data and experimental parameters used for the intensity data collection are available free of charge from the Cambridge Crystallographic Data Centre

(CCDC 1908921).

\subsection{Hirshfeld surface analysis}

Hirshfeld surfaces and their two-dimensional fingerprint [25-26] have been used to gaining additional insight into the intermolecular interactions in the title compound, based on results of single crystal X-ray diffraction studies. The Hirshfeld surface enveloping a molecule is defined by points where the molecule of interest and all the other molecules that surround it have the same contribution to the electronic density. For each point on that isosurface one has two distances: "di" the distance to the nearest nucleus internal to the surface, and "de" the distance from the point to the nearest nucleus external to the surface. The normalized contact distance $\left(d_{\text {norm }}\right)$ based on both $d_{i}$ and $d_{e}$, and the vdW radii of the atom [27]. The value of the $d_{\text {norm }}$ is positive or negative when intermolecular contacts are longer or shorter than vdW separations, respectively. Because of the symmetry between $d_{e}$ and $d_{i}$ in the expression for $\mathrm{d}_{\text {norm, }}$, where two Hirshfeld surfaces touch, both will display a red spot identical in color intensity as well as size and shape. The Hirshfeld surfaces are mapped with $\mathrm{d}_{\mathrm{i}}$, and 2D fingerprint plots presented in this paper were generated using CrystalExplorer 3.1. Graphical plots of the molecular Hirshfeld surfaces mapped with $d_{\text {norm }}$ (Eq. I) using a red-white-blue color scheme, where red highlights shorter contacts, white is used for contacts around the vdW separation, and blue is for longer contacts.

$$
\mathrm{d}_{\text {norm }}=\frac{\text { di }- \text { rivdW }}{\text { rivdW }}+\frac{\text { de }- \text { revdW }}{\text { revdW }} \text { Eq. (I) }
$$

\section{Results and discussion}

\subsection{Crystal structure description}

The complex (I) crystallizes in the triclinic system, space group $P-1$ with a $=10.987(8) \dot{\mathrm{A}}, \mathrm{b}$ $=12.096(8) \dot{A}, c=16.586(9) \AA, \alpha=88.24(2)^{\circ}, \beta=72.54(2)^{\circ}, \gamma=82.35(2)^{\circ}, V=2084(2) \AA^{3}$ and $Z=2$. Crystallographic data and structure refinement are reported in Table S1. The asymmetric unit of our cadmium(II) derivative consists of one [Cd(TClPP)(morph)] molecule. The atom numbering and thermal ellipsoids are shown in Figure 1. Selected bond distances and angles are given in Table 1 . The $\mathrm{Cd}^{2+}$ ion is positioned above the porphyrin 
core and coordinated to the four nitrogens of the porphyrin and axially by the oxygen atom of the morpholine axial ligand leady to a pentacoordinate $\mathrm{Cd}(\mathrm{II})$ porphyrin complex with a square pyramidal geometry.

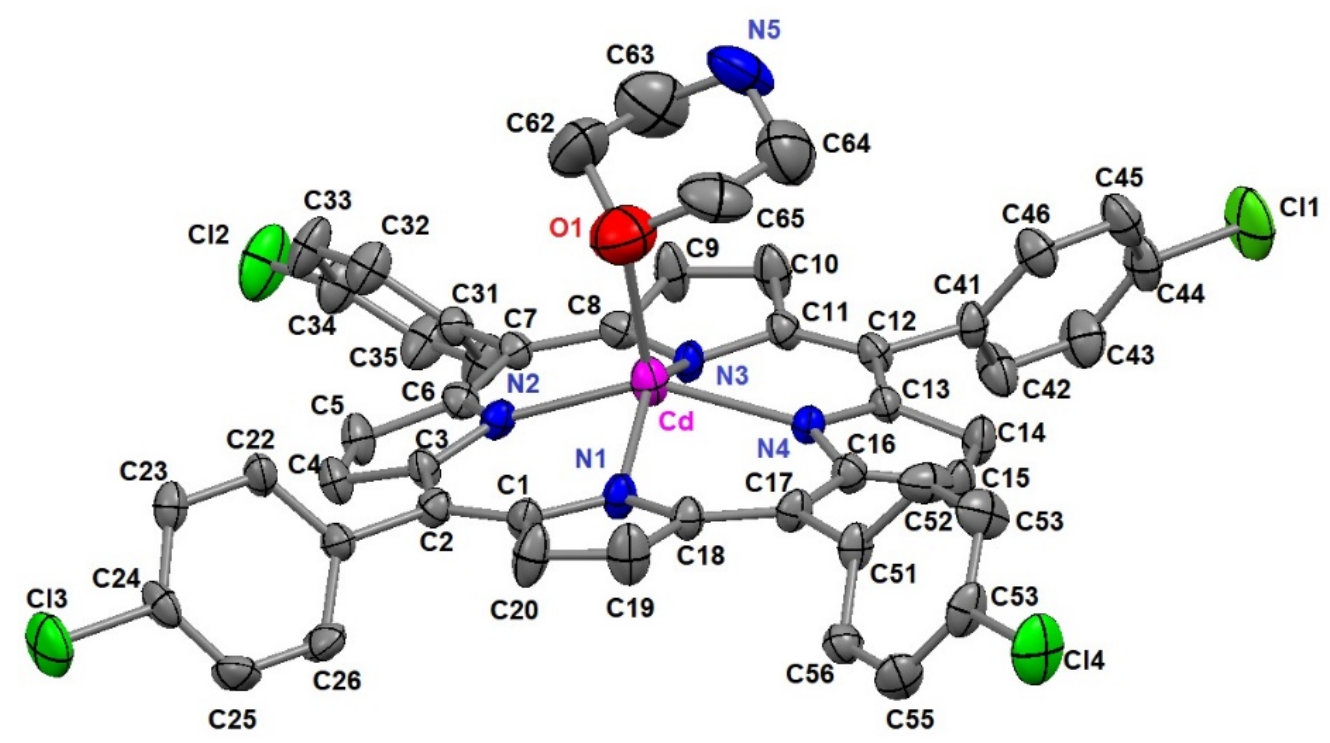

Figure 1. ORTEP diagram of [Cd(TClPP)morph] (I) with atomic numbering. Thermal ellipsoids shown at $50 \%$ probability level and the hydrogen atoms are omitted for clarity.

Table 1. Selected bond lengths $\left(\mathrm{A}^{\circ}\right)$ and angles (deg) of [Cd(TClPP)morph] (I).

\begin{tabular}{llll}
\hline Cadmium(II) coordination polyhedron & \\
\hline $\mathrm{Cd}-\mathrm{N} 1$ & $2.205(5)$ & $\mathrm{N} 1-\mathrm{Cd}-\mathrm{N} 2$ & $148.30(17)$ \\
$\mathrm{Cd}-\mathrm{N} 2$ & $2.206(5)$ & $\mathrm{N} 1-\mathrm{Cd}-\mathrm{N} 3$ & $143.04(19)$ \\
$\mathrm{Cd}-\mathrm{N} 3$ & $2.215(6)$ & $\mathrm{N} 1-\mathrm{Cd}-\mathrm{N} 4$ & $84.77(19)$ \\
$\mathrm{Cd}-\mathrm{N} 4$ & $2.191(5)$ & $\mathrm{N} 1-\mathrm{Cd}-\mathrm{O}$ & $99.3(2)$ \\
$\mathrm{Cd}-\mathrm{O}$ & $2.337(7)$ & $\mathrm{N} 2-\mathrm{Cd}-\mathrm{O}$ & $104.1(3)$ \\
& & $\mathrm{N} 3-\mathrm{Cd}-\mathrm{O}$ & $107.2(2)$ \\
\hline
\end{tabular}

Morpholine Ligand 


\begin{tabular}{llll}
\hline $\mathrm{O} 1-\mathrm{C} 62$ & $1.490(13)$ & $\mathrm{C} 62-\mathrm{O}-\mathrm{Cd}$ & $115.3(7)$ \\
$\mathrm{N} 5-\mathrm{C} 65$ & $1.399(14)$ & $\mathrm{C} 66-\mathrm{O}-\mathrm{Cd}$ & $113.9(6)$ \\
\hline
\end{tabular}

The coordination environment around the Cd(II) center in (I) is presented in Figure 2 where we can see that the morpholine ligand adopts the usual chair conformation. The fact that the morpholine is coordinated to $\mathrm{Cd}(\mathrm{H})$ via the oxygen atom and not the nitrogen atom needs to be discussed. Cadmium(II) cation is known to be a soft Lewis acid and oxygen donor ligands are known to be generally hard Lewis bases while, nitrogen donor ligand are in the borderline between hard and soft base. Therefore, since the morpholine ligand is $O$-bonded to the $\mathrm{Cd}(\mathrm{II})$ central ion (soft base - soft acid), the crystallographic data confirms the Pearson "HSAB" concept [28]. The $\mathrm{Cd}-\mathrm{O}($ morph) bond length $[2.337(7) \AA]$ is considerably close to those of related non-porphyrinic cadmium-morpholine distances which are in the range [2.323-2.371 $\AA$ ] (Table 2) [29]. The $\mathrm{Cd}-\mathrm{O}$ bond length is close to those of reported $\mathrm{Cd}(\mathrm{II})$ porphyrin complexes with oxygen atom-coordinated axial ligands (such as $\mathrm{H}_{2} \mathrm{O}$ and 2-dioxane) [30-32]. The average equatorial $(\mathrm{Cd}-\mathrm{Np})$ distance is in normal range of pentacoordinate Cd(II) metalloporphyrins with a value of 2.204(5) $\AA$. It is noteworthy that the central $\mathrm{Cd}(\mathrm{II})$ ion is, as expected, very displaced from the the $\mathrm{N} 4$ plane towards the axial ligand $(0.60 \dot{\mathrm{A}})$, leading to a domed structure of the porphyrin core of (I) (Figures 2 and 3). By the other hand, the distance between the cadmium atom and the mean plane made by the 24 -atom core of the porphyrin $\left(\mathrm{Cd}-\mathrm{P}_{\mathrm{C}}\right)$ for $(\mathbf{I})(0.741 \AA)$ is similar to those of the related five-coordinated cadmium metalloporphyrin (Table 2). 


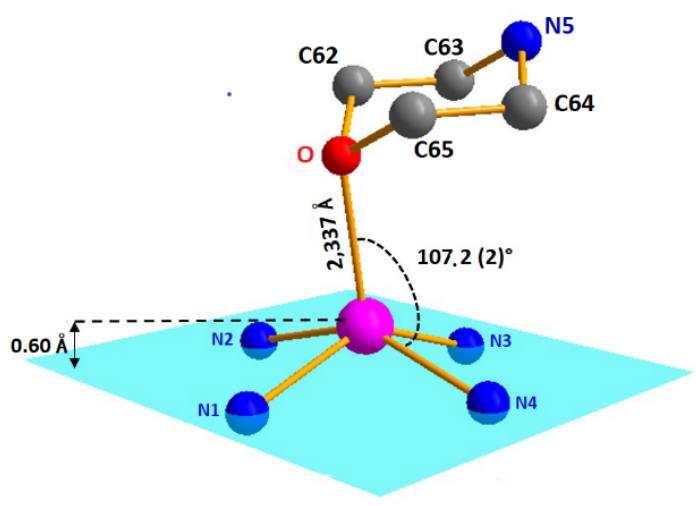

Figure 2. The coordination environment of $\mathrm{Cd}^{2+}$ ion.

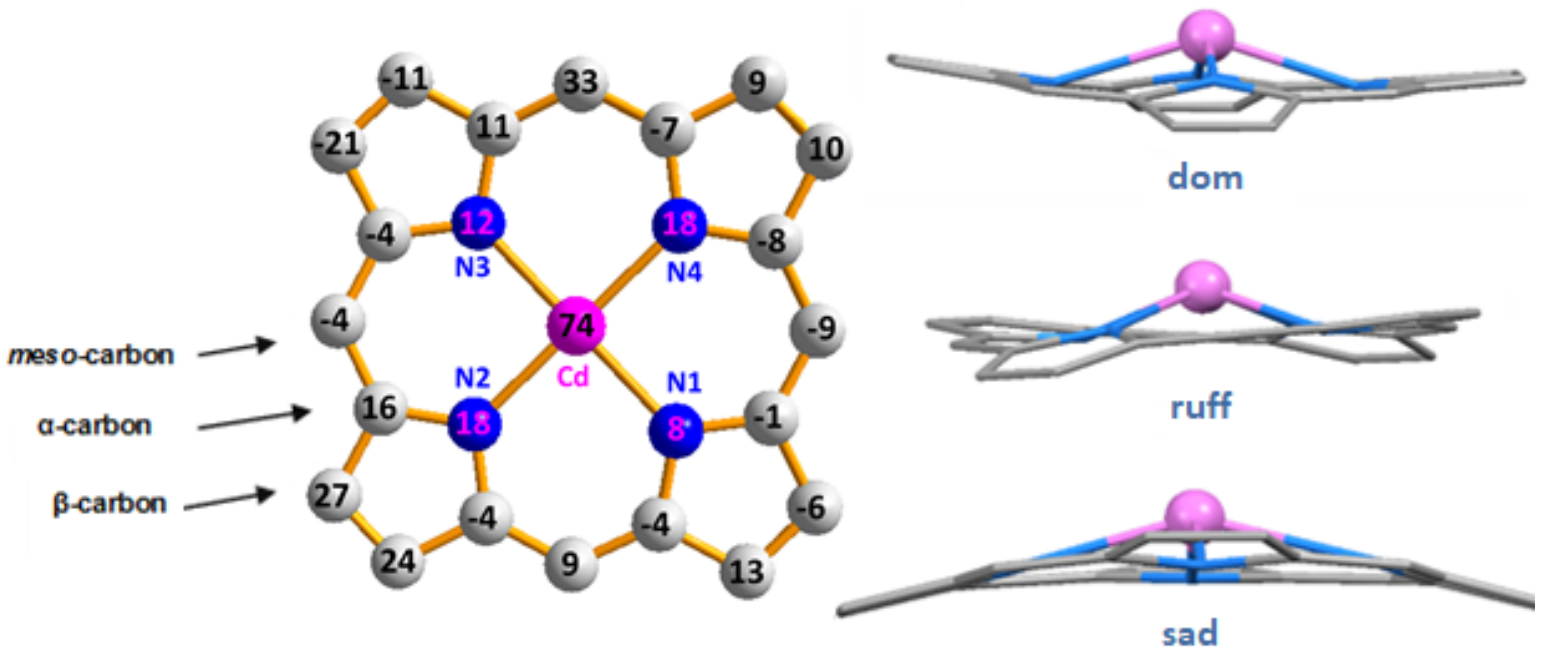

Figure 3. Formal diagrams of the porphyrinato core of [Cd(TClPP)morph] complex.

Table 2. Selected bond lengths $[\AA]$ and angles $\left[{ }^{\circ}\right]$ for complex (I) and several related Cd(II) porphyrintic and non-porphyrintic complexes.

\begin{tabular}{|c|c|c|c|c|}
\hline Complex & $\mathrm{Cd}-\mathrm{N}_{\mathrm{p}} \mathrm{a}^{\mathrm{a}}$ & $\mathrm{Cd}-\mathrm{O}_{\mathrm{ax}}^{\mathrm{b}}$ & $\mathbf{C d}-\mathbf{P}_{\mathbf{C}}{ }^{\mathbf{c}}$ & Ref. \\
\hline \multicolumn{5}{|c|}{ Porphyrinic complexes } \\
\hline [Cd(TClPP)(morph)] & $2.204(5)$ & $2.338(7)$ & 0.741 & This work \\
\hline$\left[\mathrm{Cd}(\mathrm{TPP})\left(\mathrm{H}_{2} \mathrm{O}\right)\right] \cdot(18-\mathrm{C}-6)^{\mathrm{d}, \mathrm{e}}$ & $2.230(2)$ & $2.237(2)$ & 0.803 & [30] \\
\hline [Cd(TClPP)(DMF)] & 2.197 & 2.280 & 0.824 & {$[31]$} \\
\hline$[\mathrm{Cd}(\mathrm{TPP})(2 \text {-dioxane })]^{\mathrm{d}}$ & 2.140 & $2.650-2.80$ & - & [32] \\
\hline [Cd(TClPP)(py)] & $2.203(4)$ & 0.729 & 0.729 & [31] \\
\hline$[\mathrm{Cd}(\mathrm{TPP})(\text { pip})]^{\mathrm{d}, \mathrm{f}}$ & 2.204 & - & 0.751 & [33] \\
\hline$[\mathrm{Cd}(\mathrm{TPP})(4 \text {-picoline })]^{\mathrm{d}}$ & 2.195 & - & 0.744 & [34] \\
\hline$\left[\mathrm{Cd}(\mathrm{TPP})\left(2-\mathrm{NH}_{2}-\mathrm{py}\right)\right]^{\mathrm{d}}$ & 2.204(3) & - & 0.739 & [35] \\
\hline$\left[\mathrm{Cd}(\mathrm{TPP})\left(\mathrm{N}_{3}\right)\right]^{\mathrm{d}}$ & $2.215(1)$ & - & 0.796 & [36] \\
\hline
\end{tabular}

Non-porphyrinic complexes

\begin{tabular}{llll}
\hline$\left\{\left[\mathrm{Cd}_{2} \mathrm{Cl}_{6}(\mathrm{morph})_{2}\right]\right\}_{\mathrm{n}}$ & - & $2.323-2.371$ & {$[29]$} \\
\hline$\left\{\left[\mathrm{Me}_{2} \mathrm{Cd}\right]_{3}\left[\mathrm{NH}_{2} \mathrm{~N}\left(\mathrm{CH}_{2}\right)_{4} \mathrm{O}\right]\right\}_{\mathrm{n}}$ & - & 2.655 & {$[37]$} \\
\hline a: $\mathrm{Cd}-\mathrm{Np}=$ average equatorial distance between the cadmium and the nitrogen atoms of the porphyrin ring,
\end{tabular}


b: $\mathrm{Cd}-\mathrm{O}_{\mathrm{ax}}=$ cadmium- oxygen axial ligand distance, ${ }^{\mathrm{c}}: \mathrm{Cd}-\mathrm{P}_{\mathrm{C}}$ is the distance between the cadmium atom and the mean plane made by the 24 -atom core of the porphyrin $\left(\mathrm{P}_{\mathrm{C}}\right),{ }^{\mathrm{d}}$ : TPP $=$ meso-tetraphenylporphyrinato ${ }^{\mathrm{d}}: 18-\mathrm{C}-6=$ 1,4,7,10,13,16-hexaoxacyclooctadécane (18-crown-6), ${ }^{\text {f: }}$ tetraphenylporphinato-bis(dioxane)cadmium(II), ${ }^{\text {f: }}$ pip = the piperidine.

In porphyrins, the $\pi$-conjugation favor the planar structure, however, geometrical distortion can be imposed on the macrocycle by several factors: (1) packing constraints in the crystal, (2) steric crowding caused by peripheral substituents of the porphyrin ligand, (3) the effects of intramolecular interactions between atoms of the axial ligands and the porphyrinate core, (4) intermolecular interactions, typically between two porphyrins ligands, i.e., dimeric interactions, and (5) the coordination requirements of the central metal ion itself [38]. The most characteristic types of distortions of the porphyrin core are the saddle, the dome, the ruffling and the wave distortion. Thus, the doming distortion (dom) is often observed in fivecoordinate complexes when the axial ligand causes a displacement of the metal center out of the mean plane, and the nitrogen atoms are also displaced toward the axial ligand, the ruffling distortion (ruff) is indicated by the values of the meso-carbon atoms above and below the porphyrin mean plane, the saddle distortion ( $\mathrm{sad}$ ) involves the displacement of the pyrrole rings alternately above and below the mean porphyrin macrocycle so that the pyrrole nitrogen atoms are out of the mean plane and in the waving distortions (wav), the four fragments "( $\beta$-carbon)-( $\alpha$-carbon)(meso-carbon)-( $\alpha$-carbon)-( $\beta$-carbon $) "$ are alternatively above and below the 24-atoms of the $\mathrm{C}_{20} \mathrm{~N}_{4}$ least squares plane $\left(\mathrm{P}_{\mathrm{C}}\right.$ plane). For the [Cd(TClPP)(morph)] complex, the formal diagrams of the porphyrinato cores showing the displacements of each atom from the mean plane of the 24-atom porphyrin macrocycle in units of $0.01 \AA$ is illustrated in Figure 3 where we can see that the porphyrinic core exhibits an important doming distortion and moderate ruffling and saddle deformations.

The supramolecular assemblies for the [Cd(TClPP)morph] complex is depicted in Figure 4. The molecules of this complex are connected by several weak non-conventional hydrogen bonds, such as $\mathrm{N}-\mathrm{H} \cdots \mathrm{Cl}$ involving the $\mathrm{NH}$ group of the coordinated morpholine and the $\mathrm{Cl} 2$ atom of the meso-phenylporphyrin with $\mathrm{N} 5-\mathrm{H} 5 \mathrm{~A} \cdots \mathrm{Cl} 2$ distance of $2.905(5) \dot{\mathrm{A}}$. The crystal packing is also stabilized by weak $\mathrm{C}-\mathrm{H} \cdots \mathrm{Cl}$ interactions between a pyrrolic proton of one porphyrin and a chlorine atom of an adjacent porphyrin such as the $\mathrm{C} 65-\mathrm{H} 65 \cdots \mathrm{Cl} 3$ interaction with a distance of 2.953 (7) $\AA$ (Table 3 and Figure 4). Additionally, we notice the presence of several $\mathrm{C}-\mathrm{H} \cdots \pi$ contacts, for example, the $\mathrm{C} 43-\mathrm{H} 43 \cdots \mathrm{Cg} 3$ interaction involving the carbon $\mathrm{C} 43$ of a phenyl group and the centroid $\mathrm{Cg} 3$ of a pyrrole ring of an adjacent [Cd(TClPP)morph] complex with a distance of 3,761(10) $\AA$ (Figure S1).The 
$\mathrm{C}-\mathrm{H} \cdots \pi$ interaction is observed also between the carbon $\mathrm{C} 65$ of the morpholine ring and the centroid $\mathrm{Cg} 3$ with $\mathrm{C} 65-\mathrm{H} 65 \cdots \mathrm{Cg} 3$ distance of $3.935(14) \AA$.

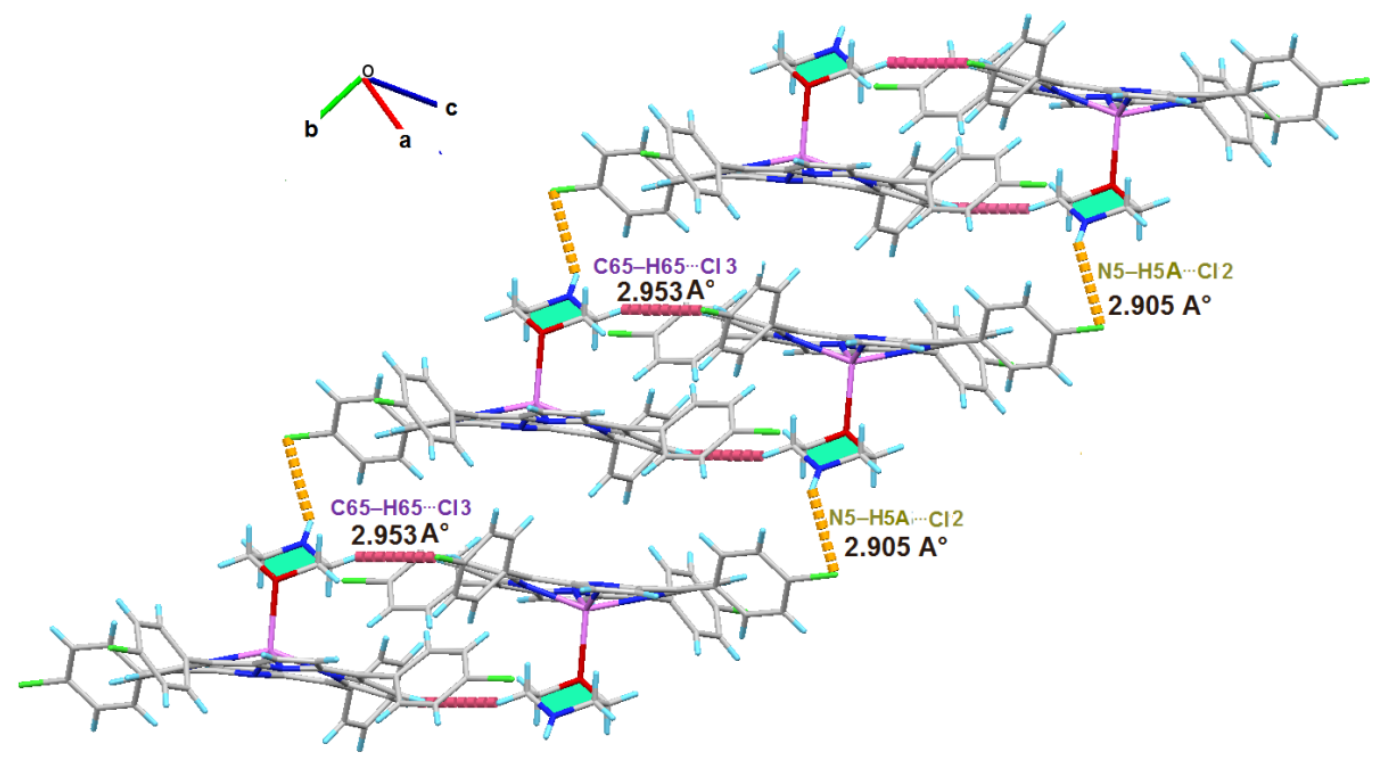

Figure 4. Schematic representation of the $\mathrm{N}-\mathrm{H} \cdots \mathrm{Cl}$ and the $\mathrm{C}-\mathrm{H} \cdots \mathrm{Cl}$ hydrogen bonds between the morpholine axial ligand and the chlorine atom of the adjacent meso-phenylporphyrin complex.

Table 3. Inter-and intramolecular interactions in (I).

\begin{tabular}{llll}
\hline $\mathbf{D}^{\mathbf{a}-H} \ldots \mathbf{A}^{\mathbf{b}}$ & Symmetry of $\mathbf{A}$ & $\mathbf{D}-\mathrm{H} \ldots \mathbf{. . A}[\AA]$ & $\mathbf{D} \ldots \mathbf{. . A}\left[{ }^{\circ}\right]$ \\
\hline $\mathrm{N} 5-\mathrm{H} 5 \mathrm{~A} \ldots \mathrm{Cl} 2$ & $-1+\mathrm{x}, 1+\mathrm{y}, \mathrm{z}$ & 147 & $2.905(5)$ \\
\hline $\mathrm{C} 65-\mathrm{H} 65 \ldots \mathrm{Cl} 3$ & $1-\mathrm{x},-\mathrm{y}, 2-\mathrm{z}$ & 152 & $2.953(7)$ \\
\hline $\mathrm{C} 14-\mathrm{H} 14 \ldots \mathrm{Cl} 2$ & $1+\mathrm{x},-1+\mathrm{y}, \mathrm{z}$ & 155 & $3.676(8)$ \\
$\mathrm{C} 20-\mathrm{H} 20 \ldots \mathrm{Cl} 3$ & $\mathrm{x}, \mathrm{y},-1+\mathrm{z}$ & 145 & $3.526(9)$ \\
$\mathrm{C} 43-\mathrm{H} 43 \ldots \mathrm{Cg} 3$ & $1-\mathrm{x}, 1-\mathrm{y}, 2-\mathrm{z}$ & 151 & $3.761(10)$ \\
$\mathrm{C} 63-\mathrm{H} 63 \mathrm{~A} \ldots \mathrm{Cg} 3$ & $\mathrm{x}, \mathrm{y}, \mathrm{z}$ & 174 & $3.935(14)$ \\
\hline
\end{tabular}

${ }^{\mathrm{a}}$ : $\mathrm{D}$ is the donor atom, ${ }^{\mathrm{b}}: \mathrm{A}$ is the acceptor atom, $\mathrm{Cg} 3$ is the centroid of the $\mathrm{N} 3 / \mathrm{C} 8-\mathrm{C} 9-\mathrm{C} 10-\mathrm{C} 11$ five membered ring.

\subsection{Hirshfeld Surface}

For a given crystal structure, the Hirshfeld surface is unique and it suggests the possibility of obtaining additional insight into the crystal [39]. Figure 5 illustrates the Hirshfeld surfaces of the title complex, showing surfaces that have been mapped over $\mathrm{d}_{\text {norm }}$. The surfaces are shown transparent for the purpose of visualizing the molecular fragment. The fingerprint plot is illustrated is given in the Figure 6 and the Hirshfeld surface, which have been mapped over a $d_{\text {norm }}$ range of -0.6 to $2.8 \AA$, are shown in Figure 5. The red spots on the Hirshfeld surface indicate the presence of close contacts, whereas areas without close contacts are shown as blue spots. The crystal packing in porphyrin is mainly controlled by the close 
contacts involving chlorine; $\mathrm{Cl} \cdots \mathrm{H}-\mathrm{C}$, which are observed as intense red spots on the Hirshfeld surface. In the crystal, $42 \%$ of the intermolecular contacts are associated with $\mathrm{H} \cdots \mathrm{H}$ contacts, $27 \%$ for the contacts between chlorine and hydrogen $\mathrm{Cl} \cdots \mathrm{H}$ and for the $\mathrm{C} \cdots \mathrm{H}$ contacts appear by the percentage contributions are $17.9 \%$. Further, the Hirshfeld surface, shows intense red spot on thes $\left(\mathrm{d}_{\mathrm{e}}\right)$ surface near the pyrrole ring which is due to close (Porph/pyr) C-H $\cdots \mathrm{Cl}$ and (ph) $\mathrm{Cl} \cdots \cdot \mathrm{H}-\mathrm{C}(\mathrm{Porph} / \mathrm{pyr})$ contacts. In addition to this, (morph) $\mathrm{H}-\mathrm{H}(\mathrm{ph})$ contacts are also seen as intense red spots.

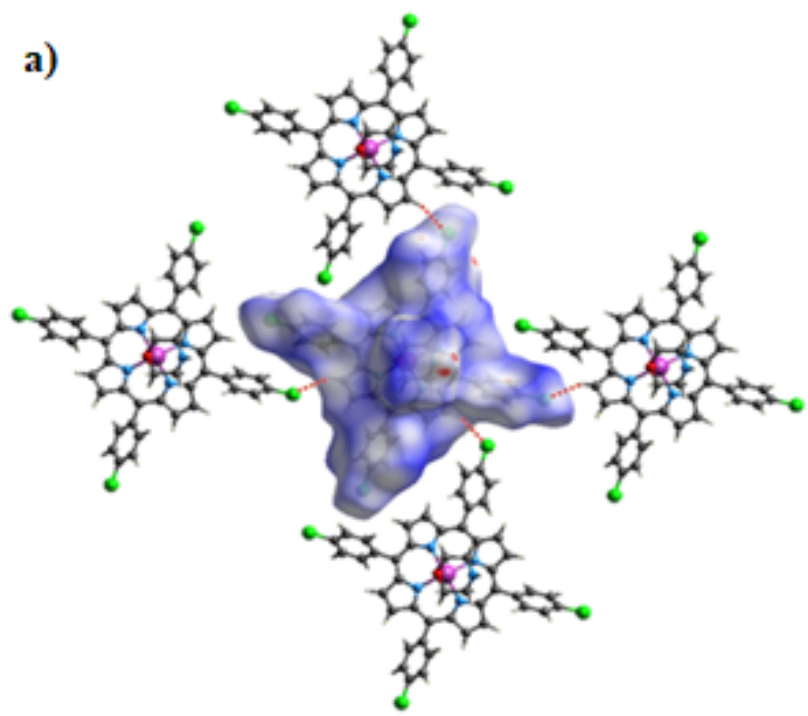

b)

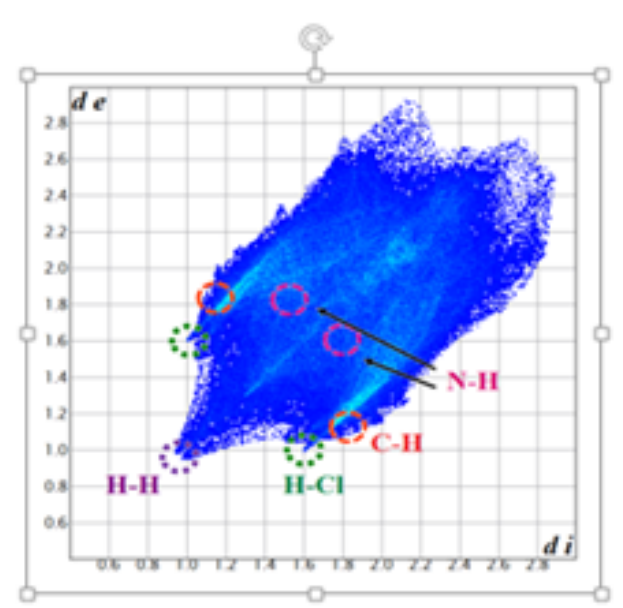

Figure 5. (a): Hirschfeld surfaces mapped over $d_{\text {norm }}$ for the title compound and (b) : Towdimensional fingerprint plot with a $d_{n o r m}$ of the title compound. 


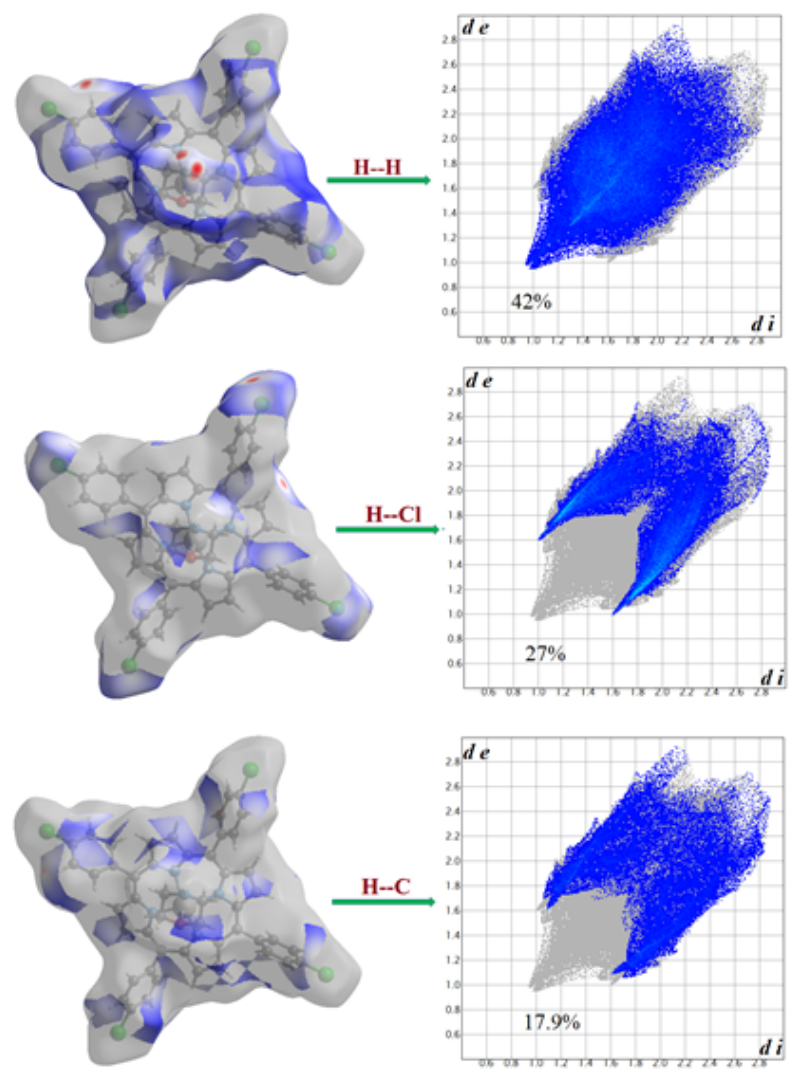

Figure 6. Two-dimensional fingerprint plots with a $d_{n o r m}$ view of the $\mathrm{H} \cdots \mathrm{H}(42 \%), \mathrm{H} \cdots \mathrm{Cl} / \mathrm{Cl} \cdots \mathrm{H}(27 \%)$ and $\mathrm{C} \cdots \mathrm{H} / \mathrm{H} \cdots \mathrm{C}(17.9 \%)$ contacts in the title compound.

\section{3. ${ }^{1} H$ NMR spectroscopy}

The ${ }^{1} \mathrm{H}$ NMR spectrum of the free-base $\mathrm{H}_{2}$ TClPP presents the expected profile for mesotetra-substituted porphyrins molecules. For instance, the signals at $\delta=8.86 \mathrm{ppm}$ correspond to the resonances of the $\beta$-pyrrolic protons. The phenyl protons $\left(\mathrm{H}_{\mathrm{o}}, \mathrm{H}_{\mathrm{o}^{\prime}} / \mathrm{H}_{\mathrm{m}}, \mathrm{H}_{\mathrm{m}}\right)$ present chemical shift values at 8.15/7.77 ppm and the NH pyrrole protons are very shielded and appears at $-2.84 \mathrm{ppm}$ in the form of a low-intensity singlet. The disappearance of the resonance of the peak corresponding to the pyrrole N-H protons was observed in the ${ }^{1} \mathrm{H}$ NMR spectrum of the metallated porphyrin [Cd(TClPP)] starting material. This spectrum of the later species is very similar to that of the free-base meso-porphyrin due to the diamagnetic nature of cadmium ion which is at the oxidation state $(+\mathrm{II})$. For $(\mathbf{I})$, the NMR spectrum (Figure S2) reveals also the characteristic signals of the axial morpholine ligand, where the $\mathrm{Ha}$ and $\mathrm{Hb}$ protons of the morpholine resonate at 3.47 and $2.64 \mathrm{ppm}$ respectively in the form of triplet and the $\mathrm{NH}$ proton of the same ligand resonates as a broad singlet around $5 \mathrm{ppm}$. These values are slightly different from those of the free morpholine molecule. 


\subsection{IR spectroscopy}

The $\left[\right.$ Cd(TCIPP)(morph)] IR spectrum has been recorded in the 4000-400 $\mathrm{cm}^{-1}$ domain (Figure S3) and is characteristic of a meso-porphyrin complex with the morpholine as axial ligand. Thus, the C-H stretching frequency of TClPP moiety is located in the $2850 \mathrm{~cm}^{-1}$ spectral region. The metalled meso-porphyrin exhibits also absorption bands attributed to the $\delta(\mathrm{CCH})$ vibration mode at $1089 \mathrm{~cm}^{-1}$. The $v(\mathrm{C}-\mathrm{Cl})$ vibration of the meso-substituted porphyrin is identified as a strong absorption band at $719 \mathrm{~cm}^{-1}$ which is in the [800-600] $\mathrm{cm}^{-1}$ domain [40-41].

The IR spectrum of the title compound exhebits also a very weak absorption band at 3293 $\mathrm{cm}^{-1}$ corresponding to $\mathrm{v}(\mathrm{NH})$ vibration of the morpholine ligand and a band at $1387 \mathrm{~cm}^{-1}$ attributed to the carbonyl stretching $v(\mathrm{C}-\mathrm{O})$ of the axial ligand.

\subsection{Photophysical properties}

The photophysical properties such as the optical absorption, the steady state emission, the fluorescence quantum yield, the fluorescence decay and the singlet oxygen profile were studied for the porphyrin free-base $\mathrm{H}_{2}$ TClPP, and the [Cd(TCIPP)] and [Cd(TCIPP)(morph)] complexes in dichloromethane solvent.

\subsubsection{UV-vis spectroscopy}

Metalloporphyrins display usually two types of absorption bands, i.e., intensive B band (known as the Soret band) locating at about $400 \mathrm{~nm}$ corresponds to $\mathrm{S}_{0} \rightarrow \mathrm{S}_{2}$ transition with the value of $\varepsilon$ (namely, molar absorption coefficient) being about $10^{5} \cdot \mathrm{M}^{-1} \cdot \mathrm{cm}^{-1}$ and four weak $Q$ bands residing at about 500- 650 corresponds to $\mathrm{S}_{0} \rightarrow \mathrm{S}_{1}$ transition with the $\varepsilon$ values being about $10^{3}-10^{4} \mathrm{M}^{-1} \cdot \mathrm{cm}^{-1}$. The normalized absorption spectra of the free base porphyrin $\mathrm{H}_{2}$ TClPP, $[\mathrm{Cd}(\mathrm{TClPP})]$ and $[\mathrm{Cd}(\mathrm{TClPP})(\mathrm{morph})]$ complexes are presented in Figure 7. The value of the $\lambda_{\max }$ of the Soret absorption band of the free base $\mathrm{H}_{2}$ TClPP appears at $420 \mathrm{~nm}$ while, the four Q bands are found at 517, 553,589, and $645 \mathrm{~nm}$. The $\lambda_{\max }$ value of the Soret band is $433 \mathrm{~nm}$ for [Cd(TCIPP)] which is red-shifted by $13 \mathrm{~nm}$ while the number of Q-band is reduced to two which are located at 568 and $609 \mathrm{~nm}$ (Table S2). The difference of the Q-band number between $[\mathrm{Cd}(\mathrm{TClPP})]$ and the free base $\mathrm{H}_{2}$ TClPP is attributed to the increase of the molecular symmetry originated from the metalation of the porphyrinic macrocycle center of the free base $\mathrm{H}_{2}$ TClPP. Whereas for (I) the $\lambda_{\max }$ values of 
the Soret and Q bands are $436 \mathrm{~nm}$ for the first band and 575, and $620 \mathrm{~nm}$ for the latter band, which are slightly red-shifted compared with those of [Cd(TCIPP)] indicating the complexation of the morpholine axial ligand. This is also the case for others related fivecoordinated metalloporphyrins [ $\left.\mathrm{M}^{\mathrm{II}}(\mathrm{TPP})(\mathrm{Morph})\right](\mathrm{M}=\mathrm{Co}, \mathrm{Cu}, \mathrm{Ni}$ and $\mathrm{Zn})$ (Table S2). It is noteworthy that the higher redshift of the absorption bands is related mainly to the important distortion of the porphyrin core [10-11]. The higher atomic radius of $\mathrm{Cd}(\mathrm{II})$ metal ion compared to the other metals $(\mathrm{M}=\mathrm{Zn}, \mathrm{Cu}, \mathrm{Ni}, \mathrm{Co}$ ) (Table $\mathrm{S} 2$ ) implies that $\mathrm{Cd}(\mathrm{II})$ is too large to fit into the central hole of the TCIPP which generates significant the deformations of the TCIPP core and the complexation of the morpholine $O$-donor axial ligand tends to increase the doming distortion by pulling out the $\mathrm{Cd}(\mathrm{II})$ metal ion from of the porphyrinato plane. The optical band gap energy $\left(E_{g}\right)$ refers to the energy difference between the HOMO and the LUMO orbitales of the porphyrin species can be calculated from the UV-visible spectrum using the Tauc plot method [42]. The $\mathrm{E}_{\mathrm{g}}$ values in $\mathrm{CH}_{2} \mathrm{Cl}_{2}$ solution are 1.960 and $1.903 \mathrm{eV}$ for [Cd(TCIPP)] and [Cd(TCIPP)(morph)] respectively, indicating that the gap energy of the metallized species are higher than that obtained for $\mathrm{H}_{2} \mathrm{TClPP}$ free base $(1.820$ eV) (Table S2) suggesting that the Cd-meso-porphyrin display interesting organic semiconducting properties [43].

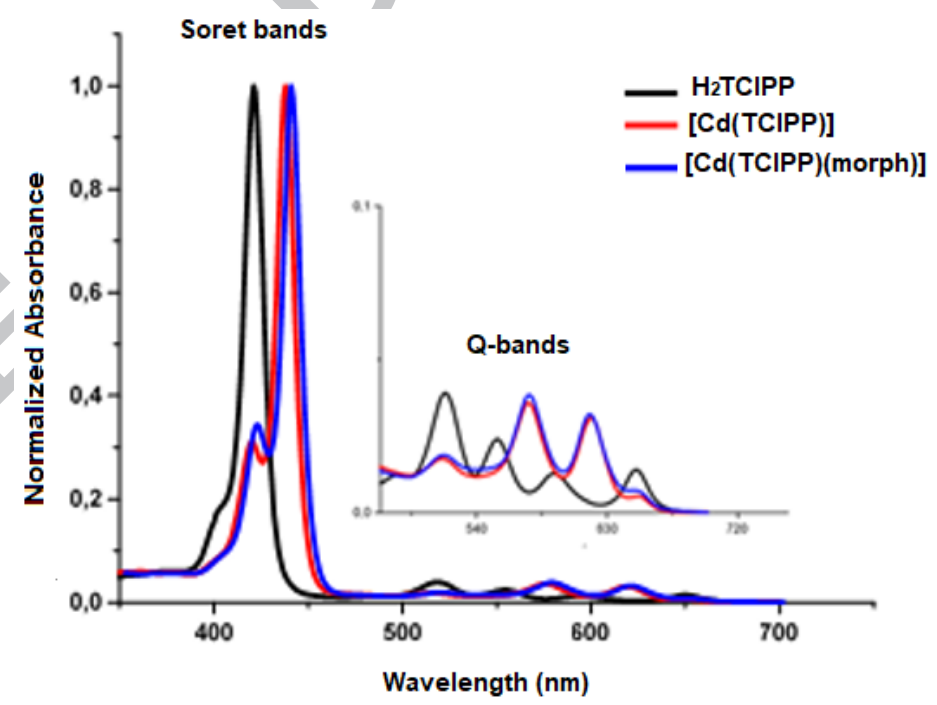

Figure 7. UV-visible absorption spectra in $\mathrm{CH}_{2} \mathrm{Cl}_{2}\left(c=10^{-5} \mathrm{M}\right)$ of $\mathrm{H}_{2} \mathrm{TClPP}$, [Cd ${ }^{\mathrm{II}}(\mathrm{TClPP})$ ], and $[\mathrm{Cd}$ II (TClPP)(morph)] (I).

\subsubsection{Steady-State fluorescence and Singlet oxygen}

The steady-state fluorescence of porphyrins was performed in order to study their electronic properties in excited state. The fluorescence emission spectra of the free base porphyrin 
( $\left.\mathrm{H}_{2} \mathrm{TClPP}\right),[\mathrm{Cd}(\mathrm{TClPP})]$ and $[\mathrm{Cd}(\mathrm{TClPP})(\mathrm{morph})]$ coordination compounds at room temperature were recorded in $\mathrm{CH}_{2} \mathrm{Cl}_{2}\left(c=10^{-6} \mathrm{M}\right)$ under the excitation wavelength of 433 $\mathrm{nm}$ (Figure-8a). Table 5 summarizes the maxima of the fluorescence of the $\mathrm{Q}(0,0)$ and $\mathrm{Q}(0,1)$ bands, the fluorescence quantum yields $\left(\phi_{\mathrm{f}}\right)$ and the fluorescence lifetimes $\left(\tau_{\mathrm{f}}\right)$ of our derivatives (I) as well as a selected species. The emission spectrum of the free base porphyrin $\mathrm{H}_{2} \mathrm{TClPP}$ in $\mathrm{CH}_{2} \mathrm{Cl}_{2}$ exhibits two well-defined emission bands near $605 \mathrm{~nm}$ $(\mathrm{Q}(0,0))$ and $657 \mathrm{~nm}(\mathrm{Q}(0,1))$ displays two emission Q bands at 650 and $717 \mathrm{~nm}(\mathrm{Q}(0,0)$ and $\mathrm{Q}(0,1)$, respectively), the emission spectrum of $[\mathrm{Cd}(\mathrm{TClPP})]$ shows a $31 \mathrm{~nm}$ (from 650 to $619 \mathrm{~nm}$ ) and a $67 \mathrm{~nm}$ (from 717 to $650 \mathrm{~nm}$ ) blue shifts of the $\mathrm{Q}(0,0)$ and $\mathrm{Q}(0,1)$ bands, respectively, accompanied by a decline of fluorescence intensity, $\phi_{\mathrm{f}}$ and $\tau_{\mathrm{f}}(\mathbf{F i g}$. 8a). Thus, after the insertion of cadmium ions into the porphyrin cavity, the emission band became blue-shifted and less intense compared to those of free-base porphyrin (Table 6), indicating that the structure of the originally flat porphyrin (free base porphyrin $\mathrm{H}_{2} \mathrm{TClPP}$ ) is distorted in out-of-plane $[\mathrm{Cd}(\mathrm{TClPP})]$ causing a dome distortion in the structure, consequently the $\phi_{\mathrm{f}}$ decrease. The decrease of the fluorescence quantum yield can be also explained by the high molar mass of $\mathrm{Cd}(\mathrm{II})$ which leads to a quenching effect, resulting in the very low $\phi_{\mathrm{f}}$ values. Which may be due to other non-radiative energy dissipation processes such as enhanced internal conversion, intersystem crossing [44-45]. The emission spectrum of complex (I) is quite similar to that of $[\mathrm{Cd}(\mathrm{TCIPP})]$ and shows that the coordination of the morpholine $O$ donor axial ligand to $\mathrm{Cd}(\mathrm{II})$ metal ion have a minor effect. This result suggests that the outof-plane distortion of porphyrin rings in $[\mathrm{Cd}(\mathrm{TClPP})]$ and $[\mathrm{Cd}(\mathrm{TClPP})(\mathrm{morph})]$ complex are relatively similar.

The Fluorescence lifetimes $\left(\tau_{\mathrm{f}}\right)$ were measured by time-correlated single photon counting technique. The representative fluorescence decays for the free base $\mathrm{H}_{2}$ TCIPP, [Cd(TCIPP)] and $[\mathrm{Cd}(\mathrm{TClPP})(\mathrm{morph})]$ are shown in Figure. S4. The $\tau_{\mathrm{f}}$ values of the free base $\mathrm{H}_{2}$ TClPP $(\sim$ $8.9 \mathrm{~ns})$ is as expected much higher than those of [Cd(TCIPP)] and [Cd(TClPP)(morph)] which are $\sim 1.6$ and $\sim 1.5 \mathrm{~ns}$ respectively (Table 6 ). We notice that the $\tau_{\mathrm{f}}$ of the cadmium porphyrins is not influenced by the axial ligand. Whereas the lifetimes of the fluorescences decrease consequence of the macrocycle distortion [46] and mainly to the large $\mathrm{Cd}$ atom. 
a)

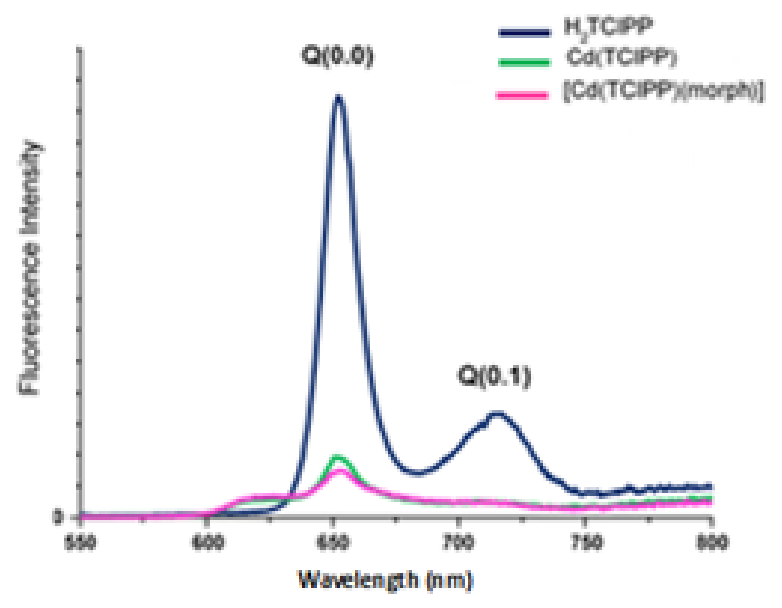

b)

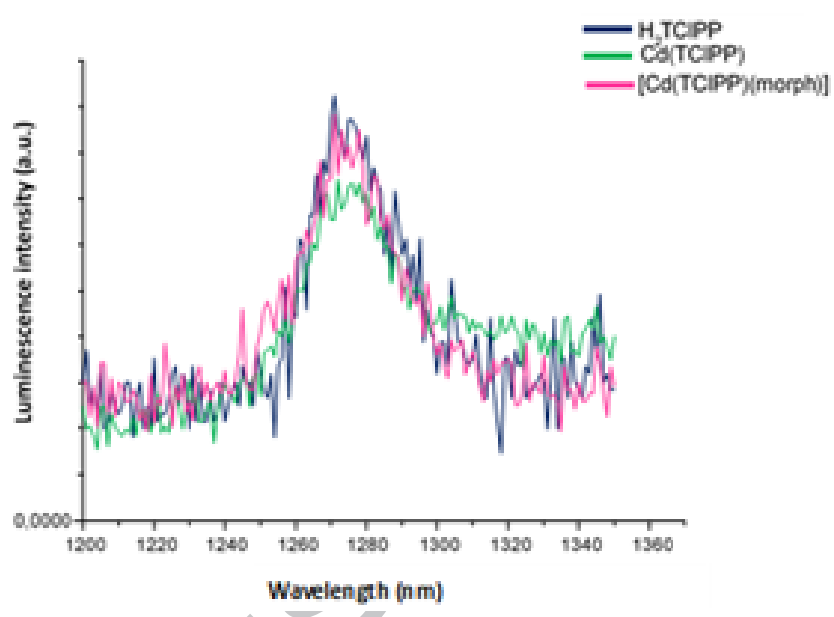

Figure 8. (a) : Fluorescence emission spectra and (b) : Singlet oxygen production spectra performed at $\lambda_{\text {ex }}=433 \mathrm{~nm}$ of $\mathrm{H}_{2} \mathrm{TClPP}$, [CdII (TCIPP) ] and [CdII (TCIPP)(morph)], in $\mathrm{CH}_{2} \mathrm{Cl}_{2}\left(c \sim 10^{-6} \mathrm{M}\right)$ at room temperature.

Table 5. Photophysical data of our synthetic species and a selection of cadmium porphyrins complexes recorded in $\mathrm{CH}_{2} \mathrm{Cl}_{2}$.

\begin{tabular}{|c|c|c|c|c|c|}
\hline Compound & $\begin{array}{ll}\text { Fluorescence }^{\mathrm{a}} \lambda_{\max }(\mathrm{nm}) \\
\mathrm{Q}(0,1) & \mathrm{Q}(0,0)\end{array}$ & $\Phi_{\mathrm{f}}^{\mathrm{b}}$ & $\tau_{\mathrm{f}}(\mathrm{ns})^{\mathrm{c}}$ & $\Phi_{\Delta}^{\mathrm{d}}$ & Ref. \\
\hline $\mathrm{H}_{2} \mathrm{TClPP}$ e & 652.9 & 0.063 & 8.2 & 0.69 & [47] \\
\hline $\mathrm{H}_{2} \mathrm{TClPP}$ & 650 & 0.075 & 8.9 & 0.49 & This work \\
\hline$[\mathrm{Cd}(\mathrm{TPP})]^{\mathrm{f}}$ & 620 & 0.065 & - & 0.69 & {$[48]$} \\
\hline$[\mathrm{Cd}(\mathrm{TMPP})]^{\mathrm{g}}$ & 624 & 0.018 & - & 0.73 & [49] \\
\hline [Cd(TClPP)] & 619 & 0.06 & 1.6 & 0.41 & This work \\
\hline$[\mathrm{Cd}(\mathrm{TClPP})(\mathrm{morph})]$ & 619 & 0.046 & 1.5 & 0.53 & This work \\
\hline
\end{tabular}

a: Fluorescence spectra of porphyrins were obtained as a function of $\lambda_{\mathrm{ex}}=433 \mathrm{~nm}$.

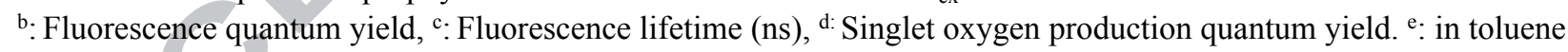
solvent, ${ }^{\mathrm{f}}$ : in ethanol solvent, ${ }^{\mathrm{g}}$ : in THF solvent.

Singlet oxygen production was detected in the infrared region, following excitation of the porphyrin at $433 \mathrm{~nm}$. Figure $8 \mathrm{~b}$ illustrates the singlet oxygen production spectra of the our synthetic compounds with the maximum emission at $1270 \mathrm{~nm}$. As seen in Table 5, the $\left[\mathrm{Cd}^{\mathrm{II}}(\mathrm{TClPP})(\mathrm{morph})\right]$ presents the highest singlet oxygen quantum yield $\left(\Phi_{\Delta}=0.53\right)$ compared to $\left[\mathrm{Cd}^{\mathrm{II}}(\mathrm{TClPP})\right]\left(\Phi_{\Delta}=0.41\right)$ and $\mathrm{H}_{2} \mathrm{TClPP}\left(\Phi_{\Delta}=0.49\right)$. The singlet oxygen quantum yield depends generally on the intersystem crossing rate. Thus, the increase of $\Phi_{\Delta}$ for the $\left[\mathrm{Cd}^{\mathrm{II}}(\mathrm{TClPP})(\mathrm{morph})\right]$ can be attributed to the structure distortion caused by the insertion of the cadmium heavy metal as well as the coordination of morpholine axial ligand. These factors are thought to promote the intersystem crossing rate through the enhanced spin-orbit coupling, consequently, increase the triplet quantum yield [50-51]. 


\subsection{Cyclic Voltammetry}

The electrochemical behavior of the free base $\mathrm{H}_{2}$ TClPP, the staring material [Cd(TClPP)] and the $[\mathrm{Cd}(\mathrm{TClPP})($ morph) $]$ complex (I) were studied by cyclic voltammetry (CV) with the tetra-n-butylammonium hexafluorophosphate $\left(\mathrm{TBAPF}_{6}\right)$ as the supporting electrolyte $(0.2$ $\mathrm{M})$ in the non-coordinating solvent $\mathrm{CH}_{2} \mathrm{Cl}_{2}$ under an argon atmosphere. In Figure 9 is illustrated the voltamogramm of (I) while in Table 6 is summarized the CV data our the free base, the starting material, complex (I) and a selection of some meso-porphyrins and zinc(II) metalloporphyrins. cadmium(II) as well as zinc(II) cations for which the correspondent metal belong to the same 12 group exhibit the $4 \mathrm{~d}^{10}$ and $3 \mathrm{~d}^{10}$ ground state electronic configurations respectively. Therefore, these cations are diamagnetic and only the oxidation and reduction waves of the porphyrin ring are observed in the voltammograms. Indeed, the $\mathrm{CV}$ of the $\mathrm{H}_{2}$ TClPP, the $[\mathrm{Cd}(\mathrm{TClPP})]$ and the $[\mathrm{Cd}$ (TClPP)(morph)] present each one a two one-electron reduction waves and three one-electron oxidation waves (Table 6). We notice that the values of the half potentials $\left(E_{1 / 2}\right)$ for the metallated porphyrin are shifted toward more negative values compared to the $\mathrm{H}_{2}$ TCLPP species. This is also the case of zinc(II) metalloporphyrins. Unfortunately, up to date, there are no reported $\mathrm{CV}$ data of $\mathrm{Cd}(\mathrm{II})$ metalloporphyrins, nevertheless, the $E_{1 / 2}$ values of complex (I) are quite smaller than those of the related zinc(II) pent-coordinated $[\mathrm{Zn}(\mathrm{TPP})(\mathrm{Him})][52]$ and $\left[\mathrm{Zn}(\mathrm{TPBP})\left(4,4^{\prime}-\mathrm{mda}\right)\right]$ [53] complexes.

The cadmium-porphyrin HOMO-LUMO gap can be expressed as the potential difference of the first oxidation and the first reduction. is given by the empirical rule of Fuhrhop et al., [54]. This energy gap is known as the electrochemical gap $\left(\mathrm{E}_{\mathrm{g}-\mathrm{el}}\right)$. The electrochemical Gap values are 2.20, 2.00 and $1.94 \mathrm{eV}$ pour our three species $\mathrm{H}_{2}$ TCIPP, [Cd(TCIPP)] and $[\mathrm{Cd}(\mathrm{TClPP})(\mathrm{morph})]$ respectively are as expected higher than those of the optical gap (see UV-visible section). We notice that the tetra-coordinated and the penta-coordinated zinc(II) complexes reported in Table 6 present $\mathrm{E}_{\mathrm{g} \text {-el }}$ values close to those of our $[\mathrm{Cd}(\mathrm{TClPP})]$ and $[\mathrm{Cd}(\mathrm{TClPP})(\mathrm{morph})]$. 
Table 6. Electrochemical data ${ }^{\text {a }}$ for $\mathrm{H}_{2} \mathrm{TClPP}$, [Cd(TClPP)], complex (I) and a selection of metalloporphyrins.

\begin{tabular}{|c|c|c|c|c|c|c|c|}
\hline & \multirow{3}{*}{$\begin{array}{l}1^{\text {st }} \text { oxidation }(\mathrm{O} 1, \mathrm{R} 1) \\
\mathrm{E}_{1 / 2}{ }^{\mathrm{b}}\end{array}$} & \multicolumn{2}{|l|}{ Oxidations } & \multicolumn{2}{|l|}{ Reductions } & \multicolumn{2}{|c|}{$\mathrm{E}_{\mathrm{g} \text {-el }}(\mathrm{eV})$} \\
\hline & & $2^{\text {nd }}$ oxidation $(\mathrm{O} 2, \mathrm{R} 2)$ & $3^{\text {rd }}$ oxidation $(\mathrm{O} 3, \mathrm{R} 3)$ & $1^{\text {st }}$ reduction $(\mathrm{R} 4, \mathrm{O} 4)$ & $2^{\text {nd }}$ reduction $(\mathrm{R} 5, \mathrm{O} 5)$ & & \\
\hline & & $\mathrm{E}_{1 / 2}$ & $\mathrm{E}_{1 / 2}$ & $\mathrm{E}_{1 / 2}$ & $E_{1 / 2}$ & & \\
\hline $\mathrm{H}_{2} \mathrm{TPP}$ & 1.02 & 1.26 & - & -1.20 & -1.55 & - & {$[55]$} \\
\hline $\mathrm{H}_{2} \mathrm{TPBP}$ & 0.95 & 1.36 & 1.48 & -1.12 & -1.53 & 2.26 & {$[53]$} \\
\hline $\mathrm{H}_{2} \mathrm{TClPP}$ & 1.00 & 1.23 & 1.53 & -1.09 & -1.41 & 2.20 & this work \\
\hline$[\mathrm{Zn}(\mathrm{TPP}]$ & $0.89 *$ & $1.18^{*}$ & - & $-1.26^{*}$ & $-1.70 *$ & - & {$[52]$} \\
\hline$[\mathrm{Zn}(\mathrm{TPBP})]^{\mathrm{c}}$ & 0.81 & 1.11 & 1.40 & -1.48 & -1.67 & 2.28 & {$[53]$} \\
\hline$[\mathrm{Cd}(\mathrm{TClPP})]$ & 0.87 & 1.09 & 1.39 & -1.19 & -1.47 & 2.00 & this work \\
\hline$[\mathrm{Zn}(\mathrm{TPP})(\mathrm{Him})]^{\mathrm{d}}$ & $0.65^{*}$ & $1.35^{*}$ & - & $-1.35^{*}$ & $-1.70 *$ & - & {$[52]$} \\
\hline$\left[\mathrm{Zn}(\mathrm{TPBP})\left(4,4^{\prime}-\mathrm{mda}\right)\right]^{\mathrm{e}}$ & 0.81 & $1.28 *$ & - & -1.38 & -1.69 & 2.31 & [53] \\
\hline$[\mathrm{Cd}(\mathrm{TClPP})(\mathrm{morph})]$ & 0.77 & 1.06 & 1.35 & -1.17 & -1.41 & 1.94 & this work \\
\hline
\end{tabular}

*: irreversible wave, ${ }^{\mathrm{a}}$ : The potentials are reported versus $\mathrm{SCE},{ }^{\mathrm{b}}: \mathrm{E}_{1 / 2}=$ half wave potential, $\mathrm{c}$ : TPBP $=$ meso-\{tetrakis-4-(benzoyloxy)phenyl]porphyrinato,

d: Him = imidazole, e: 4,4'-mda = 4,4'-diaminodiphenylmethane. 


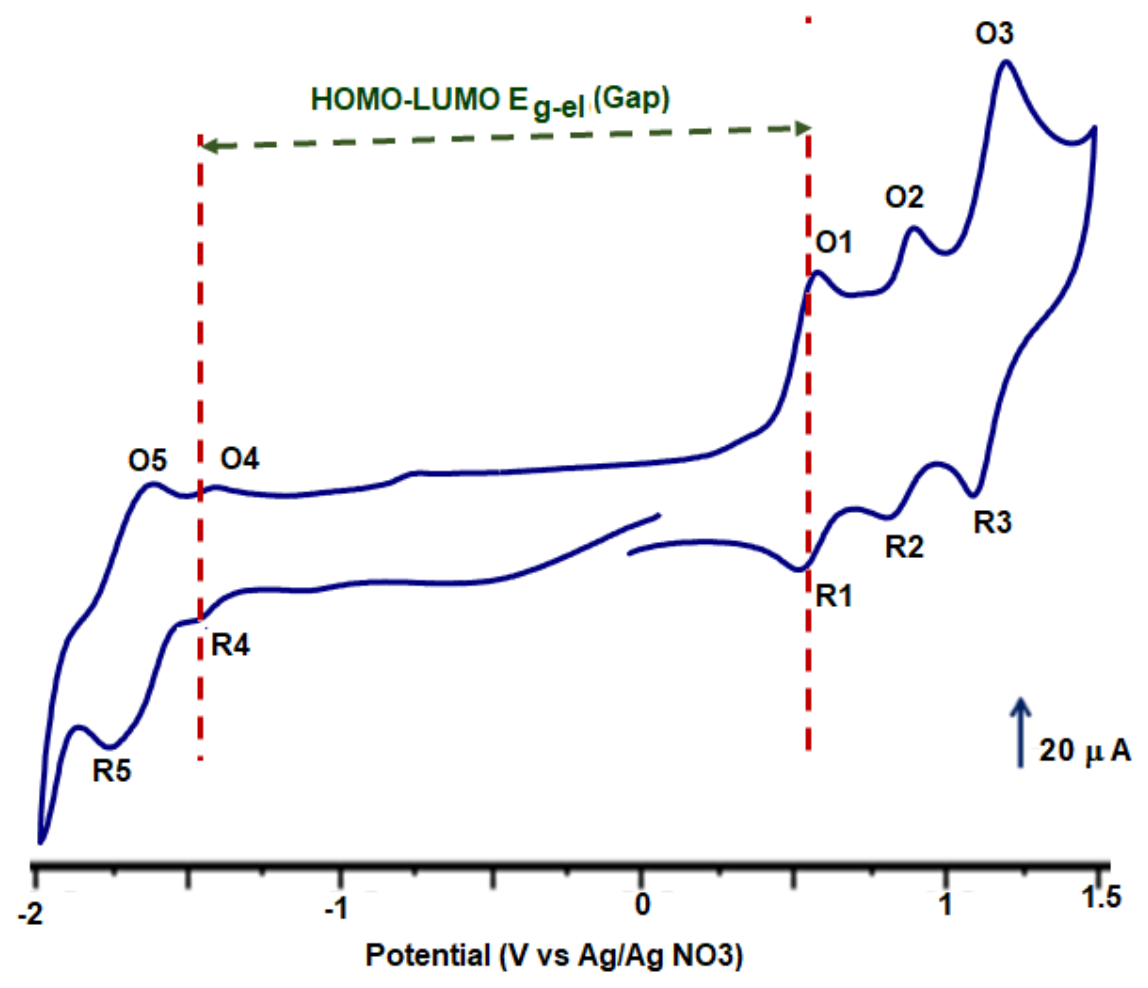

Figure 9. Cyclic voltammogram of [Cd(TClPP)(morph)] (I). The solvent is $\mathrm{CH}_{2} \mathrm{Cl}_{2}$, and the concentration is ca. $10^{-3} \mathrm{M}$ in $0.2 \mathrm{M}$ (TBAP), $100 \mathrm{mVs}^{-1}$, vitreous carbon working electrode ( $\varnothing=3$ $\mathrm{mm})$.

\section{Conclusion}

In summary, we have synthesized and characterized the five-coordinate cadmium(II) mesotetrachlorophenylporphyrin complex with the oxygen coordinated morpholine to the central metal. The structure of [Cd(TClPP)morph] (I) complex was determined by single-crystal Xray crystallographic analysis. The molecules of this complex are connected by hydrogen bonds type $\mathrm{N}-\mathrm{H} \cdots \mathrm{Cl}, \mathrm{C}-\mathrm{H} \cdots \mathrm{Cl}$, and $\mathrm{C}-\mathrm{H} \cdots \pi$. By the other hand, based on Hirshfeld topology analyses all possible intermolecular interactions occurring in the crystal structure have been quantified. The displacement of the $\mathrm{Cd}(\mathrm{II})$ metal atom out of the porphyrinato mean plane is $0.74 \AA$. This high value induces a significant porphyrinato core doming, moderate ruffling and saddle distortion. Absorption spectra reveal that the insertion of $\mathrm{Cd}(\mathrm{II})$ metal ion into TCIPP and the addition of the morpholine axial ligand are accompanied by a redshift of the Soret and $\mathrm{Q}$ bands of the $[\mathrm{Cd}(\mathrm{TClPP})]$ starting material and the [Cd(TClPP)(morph)] complex. While the Q bands of fluorescence emission spectra are blueshifted with a decrease of the fluorescence intensity, quantum yield $\left(\varphi_{f}\right)$ and lifetime $\left(\tau_{f}\right)$. The important singlet oxygen quantum yield $\left(\Phi_{\Delta}\right)$ makes this complex a good candidate to develop antibacterial and antiviral treatments. The cyclic voltammetry investigation on the $\mathrm{H}_{2} \mathrm{TClPP}$, the 
starting material $[\mathrm{Cd}(\mathrm{TClPP})]$ and complex (I) are also reported and the electrochemical gap values of these porphyrinic species were determined from the $\mathrm{CV}$ voltammogram which are slightly higher than those of the optical gap. 


\section{Supporting information}

CCDC 1908921 contain the supplementary crystallographic data of complex (I). These data can be obtained free of charge from the Cambridge Crystallographic Data Centre viawww.ccdc.cam.ac.uk/data_request/cif.

\section{Acknowledgements}

The authors gratefully acknowledge financial support from the Ministry of Higher Education and Scientific Research of Tunisia.

\section{REFERENCES}

[1] C. Zhao, F. U. Rehman, Y. Yang, X. Li, D. Zhang, H. Jiang, M. Selke, X. Wang, C. Liu , Influence of photoactivated tetra sulphonatophenyl porphyrin and TiO2nanowhiskers on rheumatoid arthritis infected bone marrow stem cell proliferation in vitro and oxidative stress biomarkers in vivo, Sci Rep., 5 (2015) 11518-11529.

[2] J. Schmitt, V. Heitz, A. Sour, F. Bolze, H. Ftouni, J. F. Nicoud, L. Flamigni, B. Ventura, Diketopyrrolopyrrole-porphyrin conjugates with high two-photon absorption and singlet oxygen generation for two-photon photodynamic therapy., Angew. Chem. Int. Ed., 54 (2014) $1-6$.

[3] K. Chang, Y. Tang, X. Fang, S. Yin, H. Xu, C. Wu, Incorporation of Porphyrin to $\pi-$ Conjugated Backbone for Polymer-Dot-Sensitized Photodynamic Therapy. Biomacromol, 6 (2017) 2128-2158.

[4] K. Kadish, K.M Smith, R. Guiard, The Porphyrin Handbook; Academic Press: New York, Vol. 1-20 (2000) 2003.

[5] M. Jurow, A. E. Schuckman, J. D. Batteas, C. M. Drain, Porphyrins as Molecular Electronic Components of Functional Devices. Coord. Chem. Rev, 254 (2010) 2297-2310.

[6] R. Paolesse, S. Nardis, D. Monti, M. Stefanelli, C. D. Natale, Porphyrinoids for Chemical Sensor Applications, Chem. Rev. 117 (2017) 2517-2583.

[7] C. Maeda, T. Taniguchi, K. Ogawa, T. Ema, Bifunctional Catalysts Based on m-PhenyleneBridged Porphyrin Dimer and Trimer Platforms: Synthesis of Cyclic Carbonates from Carbon Dioxide and Epoxides, Angew. Chem. Int. Ed., 54 (2015) $134-138$.

[8] C.-W. Lee, H.-P. Lu, C.-M. Lan, Y.-L. Huang, Y.-R. Liang, W.-N. Yen, Y.-C. Liu, Y.-S. Lin, E.W.G. Diau, C.-Y. Yeh, Novel Zinc Porphyrin Sensitizers for Dye-Sensitized Solar Cells: Synthesis and Spectral, Electrochemical and Photovoltaic Properties., Chem. Eur. J., 15 (2009 1403-1412.

[9] E. Collini, C. Ferrante, R. Bozio, Strong enhancement of the two photon absorption cross section of porphyrin J-aggregates in water, Mater. Res. Soc. Symp. Proc, 846 (2005) 39-44.

[10] Z. Valicsek, O. Horváth, G. Lendvay, I. Kikaš, I. Škorić, Formation, photophysics, and photochemistry of cadmium(II) complexes with 5,10,15,20tetrakis(4sulfonatophenyl)porphyrin and its octabromo derivative: the effects of bromination and the axial hydroxo ligand, J. Photochem. Photobiol. A., 218 (2011) 143-155. 
[11] Z. Valicsek, O. Horváth, Application of the electronic spectra of porphyrins for analytical purposes: The effects of metal ions and structural distortions, Microchem. J., 107 (2013) 4762.

[12] N. Zheng, J. Zhang, X. Bu, P. Feng, Cadmium-Porphyrin Coordination Networks: Rich Coordination Modes and Three-Dimensional Four-Connected $\mathrm{CdSO}_{4}$ and $(3,5)$-Connected Hms Nets, Cryst. Growth Des, 7 (2007) 2576-2581.

[13] C. O. Chin, Spectral Properties of Cadmium Porphyrin Apomyoglobin and Apohemoglobin Complexes, Inorg. Chem. Acta, 187 (1991) 221-225.

[14] E. Nyarko, M. Tabata, Interactions of tetracationic mercury(II), cadmium(II) and lead(II) porphyrins with DNA and their effects on DNA cleavage, J. Porphyrins Phthalocyanines; 5 (2001) 873-880.

[15] D. Lee, Y. Kanai, Biomimetic Carbon Nanotube for Catalytic $\mathrm{CO}_{2}$ Hydrolysis: First- Principles Investigation on the Role of Oxidation State and Metal Substitution in Porphyrin, J. Phys. Chem. Lett. 3 (2012) 1369-1373.

[16] T. K. Chandrashekar, V. Krishnan, Coordinative Interaction Of Morpholine With Divalent Metallo Tetraphenyl Porphyrins, J. Inorg, Nucl. Chem. 43 (1981) 3287-3290.

[17] A. D. Adler, F. R. Longo, J.D. Finarelli, J. Goldmacher, j. Assour, L. J. Korsakoff, A Simplified Synthesis for Meso-Tetraphenylporphine, Org Chem, 32 (1967) 476.

[18] P. F. Rodesiler, E. A. H. Griffith, N. G. Charles, L. Lebioda, E. L. Amma, Molecular Distortions and Solid-state 113Cd NMR: Crystal and Molecular Structure of the Piperidine Adduct of $\left(5,10,15,20\right.$-Tetraphenylporphyrinato)cadmium(II), ${ }^{113} \mathrm{Cd}$ NMR Solution and Solidstate Spectra, and Potential Energy Calculations, Inorg. Chem, 24 (1985) 4595-4600.

[19] P. G. Seybold, M. Gouterman, Fluorescence Spectra and Quantum Yields, J. Mol. Spectrosc, 31 (1969) 1-13.

[20] R. W. Redmond, J. N. Gamlin, A compilation of singlet oxygen yields from biologically relevant molecules, Photochem. Photobiol, 70 (1999) 391-475.

[21] P. J. Becker, P. Coppens, Acta Crystallogr., A30 (1974) 129-147.

[22] M. C. Burla, R. Caliandro, M. Camalli, B. Carrozzini, G. L. Cascarano, L. De Caro, C. Giacovazzo, G. Polidori, R. Spagna, SIR2004: an improved tool for crystal structure determination and refinement, J. Appl. Cryst, 38 (2005) 381-388.

[23] G. M. Sheldrick, Crystal structure refinement with SHELXL, Acta Cryst. A64 (2008) 112-122.

[24] C. F. Macrae, I. J. Bruno, J. A. Chisholm, P. R. Edgington, P. McCabe, E. Pidcock, L. Rodriguez-Monge, R. Taylor, J. Van Der Streek, P. A, Wood, Mercury CSD 2.0 - New Features for the Visualization and Investigation of Crystal Structures. J. Appl. Cryst, 41 (2008) 466-470.

[25] R. Soman, S. Sujatha, S. De, V. Rojisha, C. Parameswaran, P. Varghese, B. Arunkumar, Intermolecular Interactions in fluorinated tetraarylporphyrins: An experimental and theoretical study, Eur. J. Inorg. Chem. (2014) 2653-2662. 
[26] S. K. Wolff, D. J. Grimwood, J. J. McKinnon, M. J. Turner, D. Jayatilaka, M. A. Spackman, CrystalExplorer3.1, University of Western Australia, Crawley, Western Australia, 20052013, http://hirshfeldsurface.net/CrystalExplorer.

[27] M. A. Spackman, J. J. McKinnon, Fingerprinting intermolecular interactions in molecular crystals, J. J. Cryst.EngComm (2002), 4, 378-392.

[28] R. G. Pearson, Hard and Soft Acids and Bases, J. Am. Chem. Soc., 85(22), (1963), 35333539.

[29] W. Wang, J. Dai, catena-Poly[(dichloridocadmium)-di- $\mu$-chlorido-[bis(morpholinium-kO)cadmium]-di- $\mu$-chlorido, Acta Crystallogr. Sect. E., 67 (2011) 1144-1156.

[30] H. Toumi, Y. Belghith, J. C. Daran, H. Nasri, Aqua-(5,10,15,20-tetra-phenyl-porphyrin-ato$\kappa(4)$ N)cadmium(II)-18-crown-6 (1/1), Acta Crystallogr. Sect. E, 69 (2013) 354-368.

[31] W. S. Wun, J. H. Chen, S. S. Wang, J. Y. Tung, F. L. Liao, S. L. Wang, L. P. H. wang, S. Elango, Cadmium complexes of meso-tetra-( $p$-chlorophenyl) porphyrin:[meso-tetra-(pchlorophenyl)porphyrinato](pyridine)cadmium(II)pyridine solvate and [meso-tetra-(pchlorophenyl)porphyrinato](dimethylformamide)cadmium(II) toluene solvate, Inorg. Chem. Commun, 7 (2004) 1233-1237.

[32] P. F. Rodesiler, E. H. Griffith, P. D. Ellis, E. L. Amma, X-Ray Crystal Structure and 1I3Cd N.M.R. Spectrum of Tetraphenyl- porphinatocadmium (11)-Bis(dioxan) Solvate, J. Chem. Soc. Chem. Commun, (1980) 492- 493.

[33] P. F. Rodesiler, E. H. Griffith, N.G Charles, L. Lebioda, E.L. Amma, Molecular distortions and solid-state cadmium-113 NMR: crystal and molecular structure of the piperidine adduct of (5,10,15,20-tetraphenylporphyrinato)cadmium(II), cadmium-113 NMR solution and solidstate spectra and potential energy calculations, Inorg.Chem, 24 (1985) 4595-4600.

[34] M. P Byrn, C. J Curtis, I. Goldberg, Y. Hsiou, S.I. Khan, P. A. Sawin, S. K. Tendick, C. E. Strouse, Porphyrin sponges: structural systematics of the host lattice, J. Am. Chem. Soc. 113, (1991) 6549-6557.

[35] P. S. Zhao, F. F. Jian, L. Zhang, Synthesis, Characterization and Crystal Structure of ( $\alpha-$ Aminopyridine-N)-(5,10,15,20-tetraphenylporphyrinato) Cadmium(II) Acetone Solvate, Bull. Korean Chem. Soc., 27 (2006) 1053-1055.

[36] H. Toumi, N. Amiri, M.S. Belkhiria, J. C. Daran, H. Nasri, Di- $\mu$-azido-bis-- $(\mu-1,4,7,10,13,16-$ hexa-oxa-cyclo-octa-deca-ne)bis--(5,10,15,20-tetra-phenyl-porphyrinato)dicadmiumdisodium, Acta Cryst. Sect. E, 68 (2012) 1557-1571.

[37] L. J. Andrew, N. Hollingsworth, A. Kingsley, G. Kociok-Ko“hn, C. M. Kieran, Organocadmium Hydrazide and Hydrazine Complexes, Organometallics, 27 (2009) 26502653.

[38] K. Kadish, K. M. Smith, R. Guilard, The Handbook Porphyrins, Academic Press, New York, (2000).

[39] J. J. McKinnon, M.A. Spackman, A. S. Mitchell, Novel tools for visualizing and exploring intermol-ecular interactions in molecular crystals, Acta Crystallogr. B60 (2004) 627-668.

[40] R. M. Silverstein, G. C. Bassler, T. C. Morrill, in Spectrometric Identification of Organic Compounds. John Wiley, New York, (1991) 109-130. 
[41] J. T. Kloprogge, R. L. Frost, Raman microscopy study of basic aluminum sulfate. Part II. Raman microscopy at 77 K, Journal of Materials Science, 34 (1999) 4367-4374.

[42] J. Tauc; Grigorovici, R.; Vancu, A. Optical Properties and Electronic Structure of Amorphous Germanium, Phys. Status Solidi B, 15 (1966) 627-637.

[43] F. Mulya, G. A. Santoso, H. A. Aziz, H. D. Pranowo, Design a Better Metalloporphyrin Semiconductor: A Theoretical Studies on the Effect of Substituents and Central Ions. Advances of Science and Technology for Society, AIP Conf. Proc., (2016) 1755.

[44] F. Nifiatis, C. Jasmin Athas, K. Don Dasitha Gunaratne, Yashuda Gurung, Karissa Mae Monette and Philip Joseph Shivokevich, Substituent Effects of Porphyrin on Singlet Oxygen Generation Quantum Yields, Open. Spectros. J., 5 (2011) 1-12.

[45] D. R. Reddy B. G. Maiya, Bis(aryloxo) derivatives of tin(IV) porphyrins: synthesis, spectroscopy and redox activity, J. Porphyrins Phthalocyanines, 6 (1) (2002) 3-11.

[46] A. A. Kumar, L. Giribabu, D. R. Reddy, B. G. Maiya, New molecular arrays based on a Tin (IV) porphyrin scaffold, Inorg. Chem., 40 (2001) 6757-6766.

[47] S. Gentemann, C. J. Medforth, T. Ema, N.Y. Nelson, K.M. Smith, J. Fajer, D. Holten, Unusual picosecond $1\left(\pi, \pi^{*}\right)$ deactivation of ruffled nonplanar porphyrins, Chem. Phys. Lett., 245 (1995) 441-447.

[48] D. Kowalska, X. Liu, S. Velate, R. P. Steer, Photophysics of Soret-Excited Tetrapyrroles in Solution. I. Metalloporphyrins: MgTPP, ZnTPP, and CdTPP, U. Tripathy, J. Phys. Chem. A 112 (2008) 5824-5833.

[49] M. E. Milanesio, M. G. Alvarez, E. I. Yslas, C. D. Borsarelli, J. J. Silber, V. Rivarola, and E. N. Durantini, Photodynamic Studies of Metallo 5,10,15,20-Tetrakis(4-methoxyphenyl) porphyrin: Photochemical Characterization and Biological Consequences in a Human Carcinoma Cell Line, Photochem. Photobiol., 74(1) (2001) 14-21.

[50] J. H. Ha, G. Y. Jung, M. S. Kim, Y. H. Lee, K. Shin, Y. R. Kim, Efficiency Factors of Singlet Oxygen Generation from Core-Modified Expanded Porphyrin: Tetrathiarubyrin in Ethanol., Bull. Korean Chem. Soc., 22 (2001) 63-67.

[51] F. Nifiatis, J. C. Athas, K. D. D. Gunaratne, Y. Gurung, K. M. Monette, P. J. Shivokevich, Substituent Effects of Porphyrin on Singlet Oxygen Generation Quantum Yields, Open Spectros. J, 5 (2011) 1-12.

[52] C. L. Lin, M. Y. Fang and S. H. Cheng, Substituent and axial ligand effects on the electrochemistry of zinc porphyrins J. Electroanal. Chem., 531 (2002) 155.

[53] S. Nasri , I. Zahou, I. Turowska-Tyrk, T. Roisnel, F. Loiseau, E. Saint-Amant, H. Nasri ,Synthesis, Electronic Spectroscopy, Cyclic Voltammetry, Photophysics and Electric Properties and X-ray Molecular Structures of the dabco, pyz, 4,4'-bpy, 4-CNpy, 4,4'-mda Aza Ligands Meso-tetrakis[4-(benzoyloxy)phenyl]porphyrinato Complexes, Eur. J. Inorg. Chem. 2016 (2016), 5004-5019.

[54] J.-H. Fuhrhop, K. M. Kadish, D. G. Davis, Redox behavior of metallo oxtaethylporhyrins, J. Am. Chem. Soc., 95 (1973) 5140-5147. 
[55] K. M. Kadish, M. M. Morrison, Redox Tuning of Iron Porphyrins, J. Am. Chem. Soc. 1976, $98,3326$. 
The five-coordinate cadmium(II) meso-tetrachlorophenylporphyrin complex, containing morpholine $O$-donor as axial ligand was prepared. Their Structural and Photophysical properties have been studied.
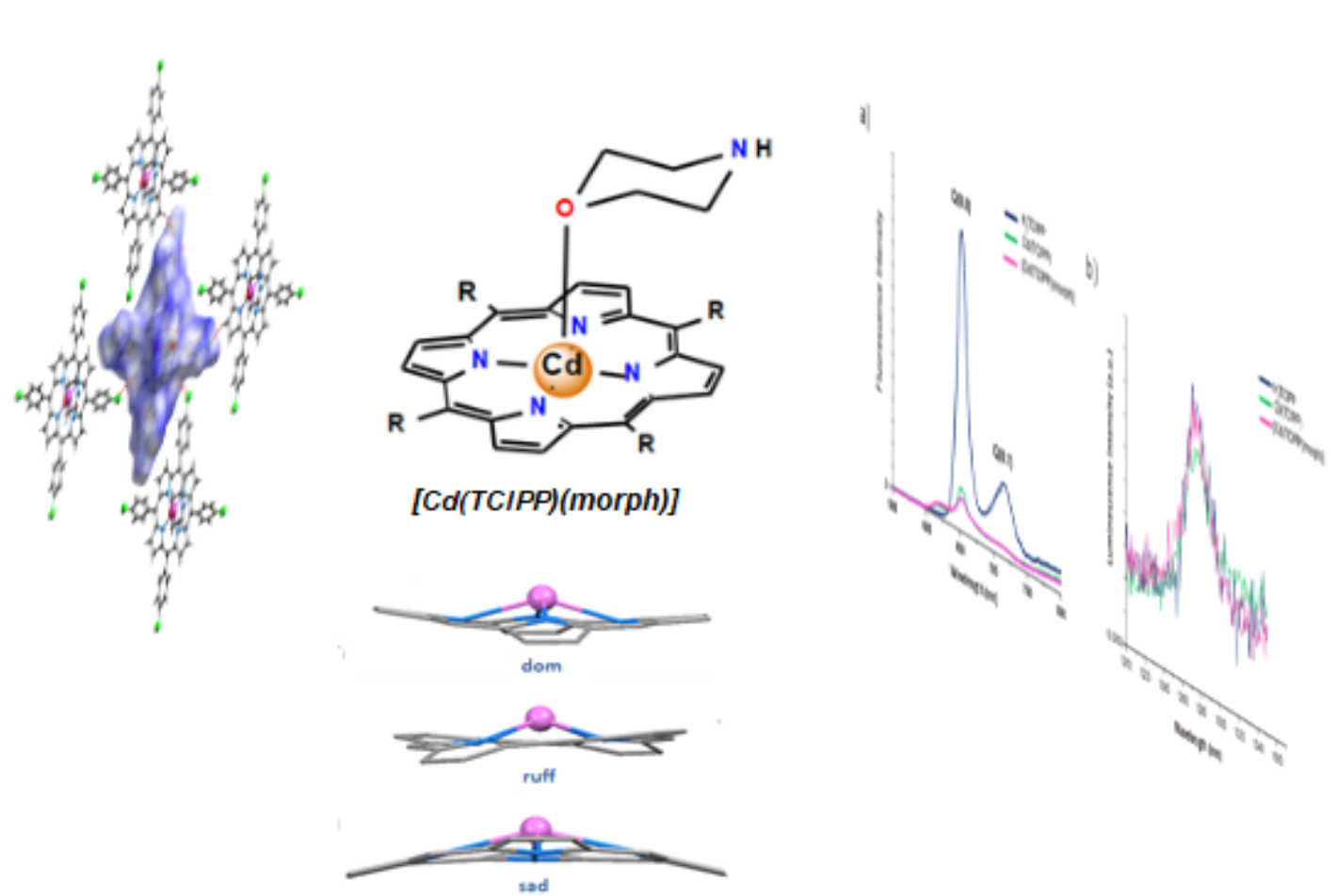